\title{
BIPV/T facades - A new opportunity for integrated collector-storage solar water heaters? Part 1: State-of-the-art, theory and potential
}

Pugsley, A., Zacharopoulos, A., Deb Mondol, J., \& Smyth, M. (2020). BIPV/T facades - A new opportunity for integrated collector-storage solar water heaters? Part 1: State-of-the-art, theory and potential. Solar Energy, 207, 317-335. https://doi.org/10.1016/j.solener.2020.06.025

Link to publication record in Ulster University Research Portal

Published in:

Solar Energy

Publication Status:

Published (in print/issue): 01/09/2020

DOI:

10.1016/j.solener.2020.06.025

\section{Document Version}

Author Accepted version

\section{General rights}

Copyright for the publications made accessible via Ulster University's Research Portal is retained by the author(s) and / or other copyright owners and it is a condition of accessing these publications that users recognise and abide by the legal requirements associated with these rights.

\section{Take down policy}

The Research Portal is Ulster University's institutional repository that provides access to Ulster's research outputs. Every effort has been made to ensure that content in the Research Portal does not infringe any person's rights, or applicable UK laws. If you discover content in the Research Portal that you believe breaches copyright or violates any law, please contact pure-support@ulster.ac.uk. 


\section{BIPV/T facades - a new opportunity for Integrated Collector- \\ 2 Storage Solar Water Heaters?}

\section{Part 1: State-of-the-art, theory and potential}

Adrian Pugsley(a) (a.pugsley@ulster.ac.uk, +44(0)28 90366264 (corresponding author) Aggelos Zacharopoulos(a) (a.zacharopoulos@ulster.ac.uk) +44(0)28 90368227

Jayanta Deb Mondol(a) (jd.mondol@ulster.ac.uk) +44(0)28 90368037

Mervyn Smyth ${ }^{(a, b)}$ (m.smyth1@ulster.ac.uk) +44(0)28 90368119

(a) Centre for Sustainable Technologies (www.cst.ulster.ac.uk), School of the Built Environment, Ulster University, Newtownabbey, BT37 OQB, Northern Ireland, UK

(b) SolaForm Ltd (www. solaform.com) c/o Ulster University, Newtownabbey, BT37 OQB, Northern Ireland, UK

\section{Keywords}

Integrated Collector-Storage Solar Water Heaters (ICSSWH); Photovoltaic-thermal $(\mathrm{PV} / \mathrm{T})$; Thermal diode; building facade; solar collector; heat removal factor

\section{Highlights}

- Two-part study proposing an alternative approach to realising BIPV/T facades

- Part 1 reviews theory \& potential, Part 2 describes prototype realisation \& testing

- Integrated Collector-Storage Solar Water Heater element reduces overheating

- Planar Liquid-Vapour Thermal Diode element reduces overnight heat losses

- Model results show that approach meets conventional performance benchmarks

\section{Abstract}

20 Building Integrated Photovoltaic Thermal (BIPV/T) systems are promising solutions

21 for serving local electricity and heat demands in Net Zero Energy Buildings (NZEB).

22 Despite BIPV/T offering clear energetic and space saving advantages compared to

23 separate BIPV and solar thermal, overheating occurs when no thermal demand exists, 24 resulting in reduced yields, stagnation damage, and excessive fluid pressures. Whilst 25 continuous fluid flows mitigate overheating, corresponding parasitic demands and 26 space requirements are significant (pumps, large storage tanks or heat rejection 27 equipment). This two-part study examines an alternative approach to BIPV/T, 28 addressing overheating by combining BIPV and Integrated Collector-Storage Solar Water Heater (ICSSWH) concepts. Solar heating capabilities of ICSSWH collectors are well established and their overnight heat loss characteristics provide passive 
31 overheating control. BIPV-ICSSWH approaches have yet to be investigated

32 extensively. This paper (Part 1 of 2 ) reviews state-of-the-art and performance

33 benchmarks in BIPV/T and ICSSWH; proposes new performance metrics enabling

34 fairer comparisons; and develops a heat transfer model for BIPV-ICSSWH façade

35 elements employing Planar Liquid-Vapour Thermal Diodes (PLVTD) to regulate

36 absorber temperatures and heat losses. Multi-day solar thermal collection,

37 photovoltaic generation, and overnight heat retention behaviours are simulated in

38 different climates. The modelling results (experimentally validated in Part 2 of 2 )

39 suggests BIPV-PLVTD-ICSSWHs with single transparent covers and $\varsigma \approx 90 \%$ PLVTD

40 diodicity achieve $\eta_{T, c o l} \approx 60 \%$ solar thermal efficiency at $\mathrm{N} \approx 0.035 \mathrm{~m}^{2} \mathrm{~K} \cdot \mathrm{W}^{-1}, \mathrm{PV} / \mathrm{T}$

41 performance ratio $\mathrm{PR}_{\mathrm{T} 3} \approx 75 \%$, and heat loss coefficient $\mathrm{U}_{\mathrm{r}, \text { sys }} \mathrm{A}_{\text {sys }} / \mathrm{u} \approx 20 \mathrm{~W} \cdot \mathrm{m}^{-3} \mathrm{~K}^{-1}$. The

42 novel BIPV-PLVTD-ICSSWH approach can reduce maximum stagnation by $20^{\circ} \mathrm{C}$

43 compared to conventional BIPV/T and therefore support NZEB realisation during

44 global efforts to tackle the climate crisis.

\section{Graphical abstract}
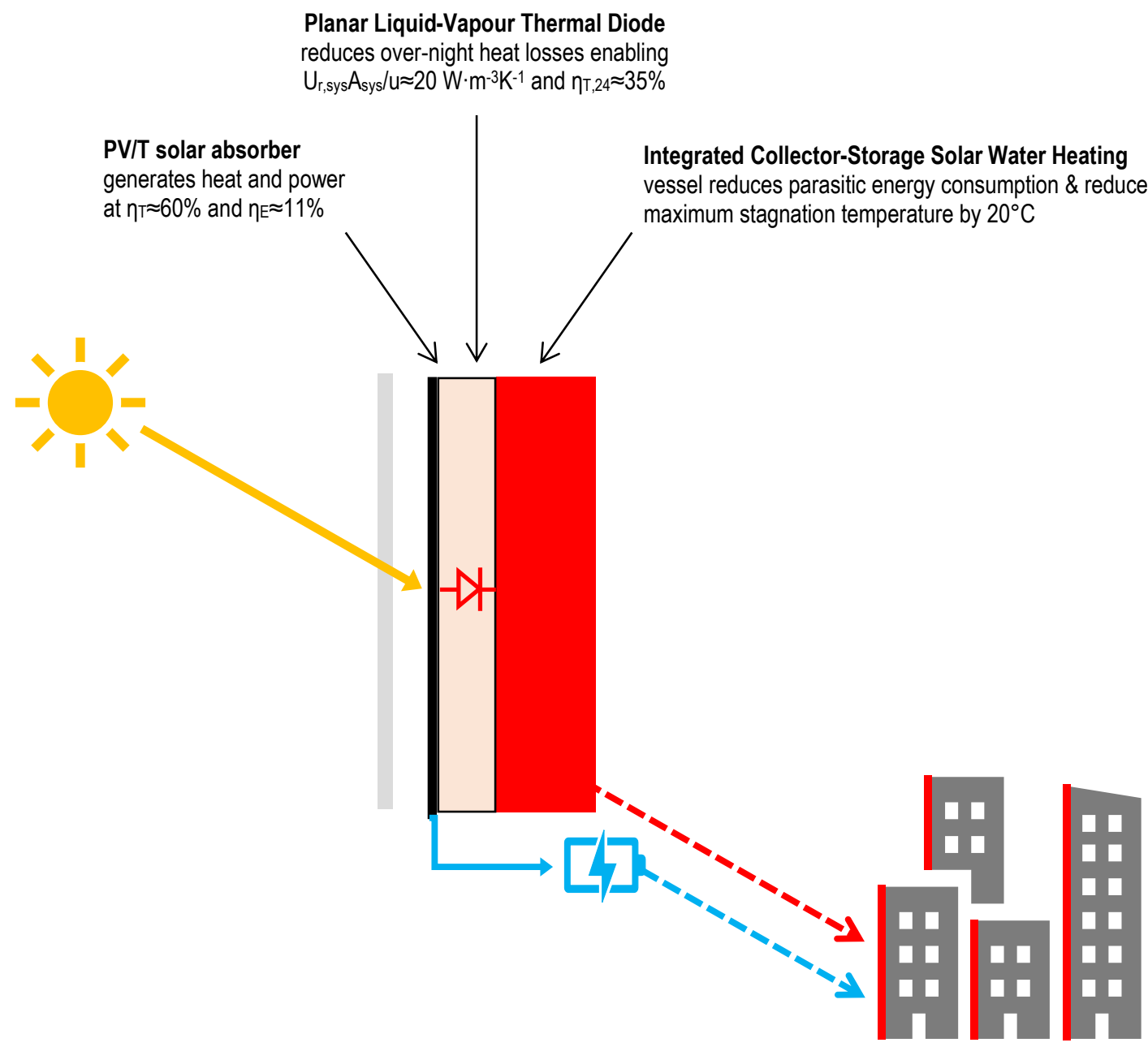

Integrated into NZEB facades to increase solar collection area whilst also reducing demands on valuable floor and roof space 


\section{Introduction}

48 Net-Zero Energy Buildings (NZEB) are increasingly being designed with Building 49 Integrated Photovoltaics (BIPV) to generate electricity and Building Integrated Solar

50 Thermal Systems (BISTS) to supply domestic hot water and thermal energy to 51 contribute towards space heating demands (COST, 2015). Approximately one-third of 52 global final energy consumption (125 of $400 \mathrm{EJ}$ annually) can be attributed to 53 residential and service sector buildings (IEA, 2018; IEA/UN, 2018) where it is primarily 54 used for space heating \& cooling (40\%) and domestic hot water production (20\%). 55 Buildings are correspondingly responsible for $\sim 39 \%$ of global $\mathrm{CO}_{2}$ emissions which need to be radically and rapidly cut in order to mitigate the climate crisis. For residential and commercial buildings in a variety of climates, BISTS can provide between $10 \%$ and $90 \%$ of space heating and domestic hot water energy demands (Smyth et al., 2006; Li et al., 2013; Drosou et al., 2014; O'Hegarty et al., 2014; Good et al., 2015; Mehdaoui et al., 2019; Beausoleil-Morrison et al., 2019; Billardo et al., 2019) and BIPV can cover similarly large proportions of building electrical loads (Good et al., 2015; Sorgato et al. 2018; Belussi, 2019; Li et al., 2019). Mismatches between energy demands and solar availability (instantaneously, diurnally and over interseasonal timescales) mean that thermal energy storage is an essential part of most BISTS and is crucial for achievement of a high solar fraction. Electrical energy storage is likewise crucial for high solar fraction BIPV systems and can be implemented in the form of batteries or as "virtual storage" via an import-export connection to the grid, perhaps in combination with load scheduling (Kats and Seal, 2012). Integrated Collector-Storage Solar Water Heater (ICSSWH) concepts have potential to reduce the costs of BISTS and to minimise loss of valuable floor space associated with conventional solar hot water storage. Very few authors (Krauter, 2004; Ziapour et al.,

72 2014; Pugsley et al., 2016) have considered the potential for combining PV and 73 ICSSWH concepts, integrating ICSSWHs into building facades (Smyth et al., 2019; 74 Harmim et al., 2019), or using them as a thermal source for heat pumps (Pugsley et al., 2017). The present work examines the synergy of combining PV and ICSSWH concepts in the BIPV and BISTS context and explores potential benefits of introducing Planar Liquid-Vapour Thermal Diodes (PLVTDs) to improve PV-thermal heat transfer and reduce overnight heat losses.

79 Traditionally, solar thermal and photovoltaic collectors have been applied as bolt-on 80 elements to building envelopes, usually fixed to roofs and tilted towards the equator 81 at the latitude angle to maximise annual insolation, or in some cases fixed to facades.

82 These building applied collectors compete for available space and can adversely affect 83 the visual aesthetics of building exteriors. Table 1 summarises insolation and average 
84 irradiance levels for three contrasting climate locations (Belfast, UK; Rome, Italy;

85 Riyadh, Saudi Arabia) at different latitudes based on 22 years of extra-terrestrial solar 86 radiation measurements and earth surface satellite imagery (NASA, 2019; Stackhouse

87 et al., 2018). Large seasonal and locational variations are apparent for horizontal $88\left(100<\mathrm{G}_{\mathrm{avg}}<600 \mathrm{~W} / \mathrm{m}^{2}\right.$ and $\left.3<\mathrm{H}_{24}<27 \mathrm{MJ} / \mathrm{m}^{2}\right)$, latitude tilted $\left(200<\mathrm{G}_{\mathrm{avg}}<600 \mathrm{~W} / \mathrm{m}^{2}\right.$ and $\left.5<\mathrm{H}_{24}<24 \mathrm{MJ} / \mathrm{m}^{2}\right)$ and sun tracking surfaces $\left(200<\mathrm{G}<800 \mathrm{~W} / \mathrm{m}^{2}\right.$ and $6<\mathrm{H}_{24}<37$ $\mathrm{MJ} / \mathrm{m}^{2}$ ). Equator-facing vertical surfaces consistently receive $200<\mathrm{G}_{\mathrm{avg}}<500 \mathrm{~W} / \mathrm{m}^{2}$ and $4<\mathrm{H}_{24}<14 \mathrm{MJ} / \mathrm{m}^{2}$ for all three locations which represents a much more seasonally stable resource, albeit of generally lower intensity. The daily insolation received by a vertically oriented equator-facing surface corresponds to $60-75 \%$ of the maximum available (relative to a sun-tracking surface) in winter and $19-46 \%$ of the maximum available energy in summer. It should be noted that much higher instantaneous irradiances ( $G_{\text {inst }} \approx 1000 \mathrm{~W} / \mathrm{m}^{2}$, occasionally higher due to cloud reflections) will occur on clear sunny days at times when the sun is aligned normal to the collector plane.

98 Building Integrated Photovoltaic-Thermal (BIPV/T) systems combine solar electricity 99 and thermal energy (hot air and/or water) generation into the building envelope. The 100 collectors form an integral part of the architecture to make aesthetically pleasing and 101 efficient use of all available insolated building envelope surfaces. This becomes 102 increasingly important for NZEBs, especially where there is a high ratio of energy 103 demand to envelope surface area, and in particular to the case of relatively tall 104 buildings (Saretta et al., 2020) where roof space for solar collectors (and likewise land 105 area for ground source heat collection) is inherently limited. Façade integrated BIPV/T 106 is a good option in higher latitude locations (such as Belfast) where significant energy 107 is required for heating and lighting in winter when the solar altitude is low and vertical 108 surfaces receive more insolation than horizontal surfaces (see Table 1). Despite 109 offering clear energetic advantages when suitable thermal demands exist, PV/T 110 collectors suffer similar stagnation and overheating problems as closed-back BIPV 111 systems (ie reduced electrical yields and eventual delamination damage) and 112 conventional solar flat plate solar water heaters (ie over-pressurisation, denaturing of 113 heat transfer fluids, damage to selective coatings, melting of polymeric components) 114 when no thermal demands exist. This can be avoided by ensuring continuous fluid 115 flows on hot sunny days but the corresponding parasitic energy requirements (eg for 116 pumps and/or heat rejection fans) typically far exceed the modest gains in electrical 117 yields and the ancillary equipment (large thermal stores and/or heat rejectors) occupy 118 valuable floor space. 


\section{0}

\begin{tabular}{|c|c|c|c|c|}
\hline & & $\begin{array}{l}\text { Cool, wet and } \\
\text { cloudy climate }\end{array}$ & $\begin{array}{c}\text { Warm and } \\
\text { sunny climate }\end{array}$ & $\begin{array}{l}\text { Hot, dry and very } \\
\text { sunny climate }\end{array}$ \\
\hline \multicolumn{2}{|c|}{ Location (Latitude, Longitude) } & $\begin{array}{c}\text { Belfast, UK } \\
(54.6 \mathrm{~N}, 5.9 \mathrm{~W})\end{array}$ & $\begin{array}{c}\text { Rome, Italy } \\
(41.9 \mathrm{~N}, 12.5 \mathrm{E})\end{array}$ & $\begin{array}{l}\text { Riyadh, Saudi Arabia } \\
\quad(24.6 \mathrm{~N}, 46.7 \mathrm{E})\end{array}$ \\
\hline \multicolumn{2}{|c|}{ Annual global horizontal insolation (a) $\left(\mathrm{H}_{\mathrm{h} 365}, \mathrm{MJ} / \mathrm{m}^{2}\right)$} & 3247 & 6073 & 7495 \\
\hline \multirow{4}{*}{$\begin{array}{c}\text { Summertime (a) average } \\
\text { daily insolation } \\
\left(\mathrm{H}_{24}, \mathrm{MJ} / \mathrm{m}^{2}\right)\end{array}$} & Horizontal surface & 15.3 & 25.8 & 26.6 \\
\hline & Sun tracking surface & 20.4 & 37.3 & 35.8 \\
\hline & Latitude tilted surface & 13.8 & 23.8 & 24.3 \\
\hline & Vertical surface & 9.4 & 11.5 & 6.9 \\
\hline \multicolumn{2}{|c|}{ Daylight hours duration (tday, hours) } & 16.2 & 14.6 & 13.4 \\
\hline \multirow{4}{*}{$\begin{array}{l}\text { Wintertime (a) average } \\
\text { daily insolation } \\
\left(\mathrm{H}_{24}, \mathrm{MJ} / \mathrm{m}^{2}\right)\end{array}$} & Horizontal surface & 2.7 & 7.7 & 14.2 \\
\hline & Sun tracking surface & 5.9 & 16.8 & 23.7 \\
\hline & Latitude tilted surface & 4.7 & 13.1 & 17.6 \\
\hline & Vertical surface & 4.4 & 12.4 & 14.3 \\
\hline \multicolumn{2}{|c|}{ Daylight hours duration (tday, hours) } & 8.4 & 9.8 & 10.9 \\
\hline \multirow{4}{*}{$\begin{array}{c}\text { Summertime }{ }^{(b)} \\
\text { typical irradiance } \\
\left(\mathrm{G}_{\text {avg }}, \mathrm{W} / \mathrm{m}^{2}\right)\end{array}$} & Horizontal surface (c) & 279 & 527 & 596 \\
\hline & Sun tracking surface ${ }^{(c)}$ & 373 & 762 & 802 \\
\hline & Latitude tilted surface (d) & 270 & 525 & 592 \\
\hline & Vertical surface ${ }^{(e)}$ & 215 & 292 & 191 \\
\hline \multirow{4}{*}{$\begin{array}{c}\text { Wintertime }{ }^{(b)} \\
\text { typical irradiance } \\
\left(G_{\text {avg }}, W / m^{2}\right)\end{array}$} & Horizontal surface (c) & 101 & 243 & 398 \\
\hline & Sun tracking surface $(\mathrm{c})$ & 221 & 530 & 665 \\
\hline & Latitude tilted surface (d) & 204 & 467 & 549 \\
\hline & Vertical surface (e) & 194 & 469 & 486 \\
\hline
\end{tabular}

a) Data from NASA (2019) based on averages for the summer months May, June, July and August and winter months November, December, January and February. Values for sun tracking collectors are based on total diffuse plus direct radiation.

b) Based on average daily insolation level divided by the estimated number of "useful" daylight hours.

c) The number of "useful" daylight hours for a sun tracking surface is taken to be 1 hour less than the total number of daylight hours to account for the fact that the sun is partially obscured by the horizon at dawn and dusk.

d) The number of "useful" daylight hours for horizontal and equator-facing latitude-tilted surfaces is taken as 2 hours less than the total number of daylight hours. This is to reflect the fact that the sun is incident at grazing angles $\left(<15^{\circ}\right.$ relative to the collector plane) during the first and last hours of the day, which results in these surfaces receiving $<25 \%$ of the available direct beam irradiance.

e) The number of "useful" daylight hours for equator-facing vertical surfaces is taken as $75 \%$ of the total number of daylight hours to account for dawn and dusk grazing incidence angles (as explained in Note "d") plus additional grazing incidence angles which occur near solar noon at low latitude locations during summer. 


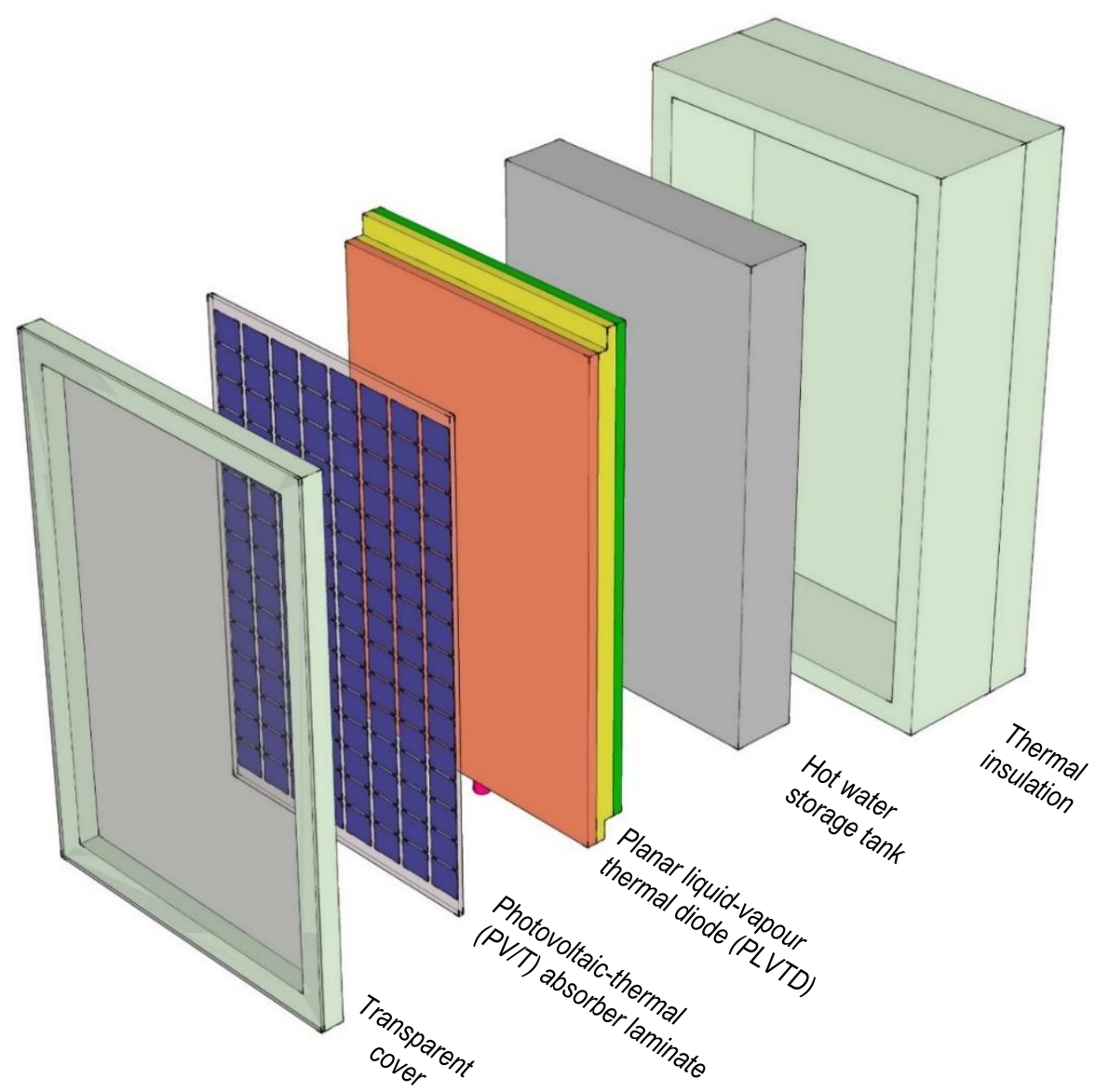

135

136

137

138

139

140

141

142

143

144

145

146

147

148

Figure 1: Key components of the BIPV-PLVTD-ICSSWH concept

Integrated Collector-Storage Solar Water Heaters (ICSSWH) are an alternative to conventional flat plate or evacuated tube collector solar water heating systems. Whilst ICSSWH systems suffer significant overnight heat losses (eg unavailability of stored heat for morning bathing etc) they offer a number of advantages in respect of cost, space, and inherent passive protection from overheating. Development of the novel BIPV-PLVTD-ICSSWH concept proposed in this two-part study has the potential to overcome key problems associated with the individual technologies (namely, BIPV/T overheating during stagnation, and ICSSWH overnight heat losses) and to realise new synergies. An exploded diagram illustrating the component parts of a BIPV-PLVTDICSSHW collector is shown in Figure 1. The present paper (Part 1 of 2) introduces the BIPV-PLVTD-ICSSWH concept; reviews the fundamental operating principles of PV/T, ICSSWH and PLVTD components; and establishes state-of-the-art performance benchmarks. A new heat loss performance metric $\left(U_{r, s y s} A_{s y s} / u\right.$ with units $\left.\mathrm{W} \cdot \mathrm{m}^{-3} \cdot \mathrm{K}^{-1}\right)$ is proposed to enable ICSSWHs of differing sizes and shapes to be compared more fairly. New thermal and electrical performance metrics (diurnal thermal efficiency $\eta_{T, 24}$ and $\mathrm{PV} / \mathrm{T}$ performance ratio $\mathrm{PR}_{\mathrm{T} 3}$ ) are also proposed to facilitate better comparisons 
154 between different technologies. An energetic model of the BIPV-PLVTD-ICSSWH 155 concept is presented and some key theoretical considerations concerning heat removal 156 factors and thermal diodicity are discussed. The energy model has been used to predict 157 temperatures, solar thermal collection, photovoltaic generation, and overnight heat 158 retention behaviours over multi-day periods in a variety of climates. Modelling results 159 have been compared with appropriate benchmarks to highlight the potential benefits 160 of the BIPV-PLVTD-ICSSWH concept in the context of applications in NZEB facades. 161 The concluding part of the study is presented in a separate paper (Part 2 of 2) which 162 describes realisation and laboratory testing of a prototype to demonstrate operation 163 and validate the theoretical model.

2 State-of-the-art in relevant technologies

\section{$2.1 \quad$ Photovoltaic-thermal (PV/T) systems}

167 The concept of combining PV and thermal absorbers into a single collector initially 168 arose from a need to remove unwanted heat from early PV modules (especially those 169 incorporating concentrating reflectors) whose electrical efficiency was compromised by 170 high temperatures. The first PV/T collectors were designed to use this "waste" heat for 171 residential water and air heating applications. Zondag (2008) gives a comprehensive 172 review of 30 years of flat plate $\mathrm{PV} / \mathrm{T}$ collector development and more recent reviews 173 are given by Michael et al. (2015); Besheer et al. (2016) and Sultan \& Efzan (2018),

174 amongst others. Whilst popularity of PV systems has sky-rocketed in recent years 175 owing to rapidly declining costs, PV/T systems have failed to achieve commercial 176 success. Recent academic advances in PV/T collector development have explored the 177 use of nanofluids to improve heat transfer and nanomaterials for phase change thermal 178 storage or optical filtering (Abdelrazik et al., 2018; Das et al., 2018). Recent advances 179 in system-level approaches, applications, and economics of BIPV/T (Buonomano et al., 180 2016; Yang \& Athienitis, 2016; Barone et al., 2019) include studies on heat pump 181 integration (Good et al., 2015; Calise et al., 2016; Qu et al., 2016) and the 182 multifunction façade context (Li et al., 2019; Tian et al., 2019).

\section{$183 \quad 2.2 \quad$ Electrical behaviour of PV/T systems}

184 Electrical efficiencies of PV/T collectors are typically 5 to $15 \%$ depending on PV cell 185 material type and heat delivery temperature. The main drivers of electrical efficiency 186 (assuming no shading) are the inherent PV cell efficiency characteristics; cell operating 187 temperature; and optical losses. Individual PV cells each nominally produce $\sim 0.5 \mathrm{~V}$, 
188 although voltage reduces with increasing temperature and tends towards zero under 189 low irradiance or short circuit conditions. Current flows depend upon PV cell material 190 type and are proportional to area and incident irradiance level; inversely proportional 191 to applied electrical load resistance (tending to zero under open circuit conditions); 192 and typically increase slightly with increasing cell temperature. Cells connected 193 together in series all operate at the same current, while cells connected in parallel all 194 operate at the same voltage. Temperature gradients sometimes exist over PV/T 195 absorber surfaces causing cells to operate at different maximum power points. 196 Operating point voltage differences caused by temperature non-uniformities can 197 significantly reduce electrical efficiency if cells are connected in parallel but generally 198 have minimal effect on series connected cells. Monocrystalline (mc-si) and 199 polycrystalline (pc-si) silicon PV cells, and amorphous silicon (a-si), Cadmium Telluride 200 (CdTe) and Copper Indium Gallium Selenide (CIGS) thin film cells have all successfully 201 been used for PV/T. Crystalline silicon typically offers high efficiency $\left(15<\eta_{E}<18 \%\right)$ at 202 low temperatures but pronounced reductions occur with increasing temperature. Lower 203 efficiencies $\left(6<\eta_{E}<12 \%\right)$ are typical for thin film cell types. Multijunction cells, formed 204 of several layers of different PV materials with different band gaps, have the highest 205 known photovoltaic efficiencies but are expensive and typically only used for spacecraft 206 applications. Inclusion of transparent covers over PV/T absorbers significantly reduces 207 heat loss but correspondingly increases optical losses and hence reduces electrical 208 efficiency. Experimental work by Guarracino et al. (2019) found that transparent 209 covers can significantly reduce electrical efficiency, especially at oblique solar incidence 210 angles when refection losses are typically more significant than cell temperature 211 effects. Zondag (2008) suggests uncovered BIPV/T façade electrical efficiencies are 212 commonly enhanced by $\sim 10 \%$ compared to non-ventilated BIPV due to beneficial heat 213 removal but can be compromised by $\sim 10 \%$ compared to conventional naturally 214 ventilated roof-mounted PV modules if heat delivery temperatures are high (similar 215 findings are reported by Fuentes et al., 2018). Net electrical yields from BIPV/T 216 systems can be lower than those from BIPV owing to the parasitic electricity 217 consumption by pumps and fans facilitating heat removal. Parasitic consumption 218 increases when buildings have no significant heat demand (eg no space heating 219 required in summer and relatively low hot water usage) and waste heat rejection 220 equipment becomes necessary to prevent overheating damage caused by stagnation 221 (delamination, excess fluid pressures, etc).

222 Cells and modules are commonly characterized with reference to Standard Test 223 Conditions (STC at $\mathrm{G}=1000 \mathrm{~W} / \mathrm{m}^{2}$ irradiance with spectrum AM1.5 and $\mathrm{T}_{0}=25^{\circ} \mathrm{C}$ cell 
224 temperature) using performance metrics derived from current-voltage curves. Key

225 metrics (defined in Equations 1 to 4 ) include short circuit current $\left(\mathrm{I}_{\mathrm{sc}}\right)$, open circuit 226 voltage $\left(V_{o c}\right)$, electrical power delivered at the maximum power point $\left(q_{E, m p p}\right)$, fill factor 227 (FF), voltage-temperature coefficient $\left(K_{V: T}\right)$, current-temperature coefficient $\left(K_{I: T}\right)$ and 228 voltage-irradiance coefficient $K_{V: G}$. Performance deviates from the ideal current-voltage 229 curve $\left(F_{\text {ideal }}=1\right)$ with increasing irradiance and increasing temperature such that 230 typical real values are $0.75<\mathrm{FF}_{\mathrm{STC}}<0.85$ and $K_{V: T}=-0.45 \% / \mathrm{K}$ for c-si and $2310.5<\mathrm{FF}_{\mathrm{STC}}<0.7$ and $K_{V: T}=-0.25 \% / \mathrm{K}$ for thin film (DGS, 2008). Current-temperature 232 coefficients $\left(K_{I: T}\right)$ and are usually positive but an order of magnitude smaller than $K_{V: T}$. 233 According to Santbergen et al. (2010) non-linear voltage-irradiance coefficient values 234 are typically $K_{V: G} \approx 100 \%$ for irradiances of primary interest $\left(400<\mathrm{G}<1200 \mathrm{~W} \cdot \mathrm{m}^{-2}\right)$, $235 K_{V: G} \approx 80 \%$ for cloudy conditions $\left(\mathrm{G}=100 \mathrm{~W} \cdot \mathrm{m}^{-2}\right)$ and $K_{V: G}<50 \%$ for very low irradiances $236\left(\mathrm{G}<50 \mathrm{~W} \cdot \mathrm{m}^{-2}\right)$.

237 The electrical output of a conventional PV module operating under realistic conditions 238 deviates significantly from that occurring under STC owing to a variety of cell 239 temperature and irradiance effects. Cell temperatures $\left(T_{0}\right)$ are determined by the 240 ambient temperature $\left(T_{a}\right)$ and incident irradiance level $(G)$ as well as module mounting 241 arrangements and local wind speed effects. Irradiance incident on the PV cell surface 242 is determined by the prevailing irradiance level and spectrum (which are functions of 243 latitude, time of day, module mounting angle, and local weather conditions) as well as 244 optical losses associated with cell coverings (eg cover glass, cell encapsulation 245 materials, front-of-cell electrical contacts etc). Deviations relative to STC are further 246 pronounced in the case of PV/T modules owing to the influence of the fluid temperature $247\left(\mathrm{~T}_{3}\right)$ upon the cell temperature $\left(\mathrm{T}_{0}\right)$ and because transparent covers required to reduce 248 heat loss inherently reduce the effective transmissivity $(\tau)$. A sensible approach to the 249 characterization of PV/T module electrical performance is therefore to define a 250 Performance Ratio comparing the device's maximum electrical power output $\left(q_{E, \text { mp }, \text { T3 }}\right)$ 251 at operating fluid temperature $\left(T_{3}\right)$ relative to a chosen reference value. Santbergen 252 et al. (2010) use the standard maximum power output ( $q_{\mathrm{sTc}}$ ) as the reference value 253 (PRstc as defined by Equation 5 ). We propose an alternative ( $P R_{T 3}$ as defined by 254 Equation 6) which takes the reference value as being the power output of an ideal PV/T 255 module with perfect optical $(\tau=1)$ and heat transfer characteristics $\left(F=1\right.$ so that $\left.T_{0}=T_{3}\right)$ 256 and full coverage of the absorber by PV cells $\left(A_{0}=A_{1}\right)$. Based on work of other authors 257 (notably Zondag et al., 2003; Santbergen et al., 2010 and Guarracino et al., 2019) 258 suitable benchmark values are $\mathrm{PR}_{\mathrm{T} 3}=85 \%$ and $\mathrm{PR}_{\mathrm{T}_{3}}=75 \%$ for uncovered and covered 259 collectors respectively. 
$261 \quad K_{V: T}=\frac{V_{o c, T_{0}}-V_{o c, S T C}}{V_{o c, S T C}\left(T_{0}-25\right)}$

\subsection{Thermal behaviour of PV/T systems}

267 Solar thermal efficiencies of PV/T collectors are typically $60<\eta_{T}<80 \%$ when working

268 fluid and ambient temperatures are equal (zero loss condition) but commonly $\eta_{T}<30 \%$

269 for collectors producing domestic hot water in cool climates. Cell type and packing

270 factor; front-of-cell electrical contacts or transparent conductors; absorber substrate

271 characteristics; and encapsulation material properties, together determine the optical

272 properties and heat transfer characteristics of PV/T absorbers. Solar thermal efficiencies

273 of PV/T absorbers are generally lower than those of dedicated solar heat collectors

274 because absorption coefficients $(0.7<\alpha<0.9)$ and emissivities $(0.2<\varepsilon<0.6$ bare or

$2750.7<\varepsilon<0.9$ encapsulated) of PV cells are inferior to those achieved by solar selective 276 coatings ( $\alpha \approx 0.95$ and $\varepsilon \approx 0.1$ ). Thermal efficiencies are also inherently reduced because a 277 proportion of the input solar energy is converted to electricity when a suitable load is 278 connected (Guarracino et al., 2019). High emissivities of PV cells and encapsulation 279 materials increases radiative heat losses which become particularly significant at high 280 heat delivery temperatures. Typical PV/T collector constructions are discussed in detail 281 by Santbergen et al. (2010) and Dupeyrat et al. (2011). Most liquid-heating PV/T 282 collectors take the form of individual PV cells or whole module laminates glued or bonded 283 to conventional metal solar thermal absorbers (eg sheet-and-tube, flow channel, or roll284 bond types). High thermal conductance through bonding layers joining PV cells to 285 absorber substrates is required to minimise absorber temperatures, minimise heat 286 losses, and maximise solar thermal efficiency. Likewise, convective heat transfer 287 between absorber substrates and working fluids should be maximized. Zondag (2008) 288 discusses $\mathrm{PV} / \mathrm{T}$ collectors featuring overall conductances in the range 40 to 
$250 \mathrm{~W} \cdot \mathrm{m}^{-2} \mathrm{~K}^{-1}$ with the poorest example of heat transfer occurring in a collector

290 featuring a $5 \mathrm{~mm}$ silicone bonding layer where cell-to-fluid temperature difference was

$29112^{\circ} \mathrm{C}$ corresponding to $>10 \%$ reduction in thermal output and $\sim 5 \%$ reduction in

292 electrical yield. Dupeyrat et al. (2011) fabricated a high efficiency collector with $0.5 \mathrm{~mm}$

293 thick Ethylene-Vinyl Acetate bonding layer achieving $700 \mathrm{~W} \cdot \mathrm{m}^{-2} \mathrm{~K}^{-1}$ between PV cells and

294 a $1.2 \mathrm{~mm}$ roll-bond aluminium thermal absorber. Fragile PV cells must be protected

295 against damaging mechanical forces (eg torsions during handling, wind loads, and

296 impacts from hail or vandalism); protected against water ingress; and electrically

297 isolated from metal substrates. External protection usually takes the form of a glass

298 or transparent polymer layer bonded to the front side of the PV cells. This can be

299 supplemented by one or more tertiary transparent covers to reduce heat loss in cases

300 where high delivery temperatures or operation in cold and windy climates is required

301 (ie heat delivered at $>20^{\circ} \mathrm{C}$ higher than ambient). Like conventional solar thermal

302 collectors, $\mathrm{PV} / \mathrm{T}$ must be protected against high stagnation temperatures (especially

303 when fitted with tertiary transparent covers) and withstand thermal shocks caused by

304 rapid changes in climatic conditions or fluid flow transients (eg cold water flowing into

305 hot collectors). Damage can occur due to high fluid pressures; differential thermal

306 expansion stresses; melting and UV light degradation of polymeric component

307 materials. Stagnation damage prevention requires continuous operation of fluid

308 circulation systems during hot and sunny periods and heat rejection systems may be

309 required when thermal demands are low or intermittent.

\section{$3102.4 \quad$ Integrated Collector-Storage Solar Water Heaters}

311 Solar water heating systems typically have three main components: the collector, the

312 heat transfer system, and the storage vessel. Storage vessels in conventional pumped

313 solar water heating systems tend to be bulky and consume valuable floor space. In hot

314 climates, thermosiphon solar water heaters with close-coupled storage tanks are

315 popular owing to their passive operation, simple installation, externally located storage

316 tank, and relatively low cost. Integrated Collector-Storage Solar Water Heaters

317 (ICSSWH) combine the solar absorber and the thermal storage tank into a single unit

318 to save floor space within the building and to reduce the amount of pumping energy

319 required. They are usually passive devices in which part of the storage tank envelope

320 is used as a solar absorber. This minimises system size and quantity of material

321 required for manufacturing, leading to lower unit costs (Tripanagnostopoulos \&

322 Souliotis, 2006), less embodied energy, and greater space efficiency. The greatest

323 drawback of ICSSWHs and close-coupled thermosiphon solar water heaters is that a 
324 large area of storage vessel surface is inherently exposed to the outdoor environment 325 and thus susceptible to heat loss, especially in cold and windy climates. Smyth et al. 326 (2006) provides a comprehensive review from a technical perspective and traces 327 development history back to the 1800s. A more recent review by Singh et al. (2016) 328 attempts to categorise designs according to whether they are non-concentrating (eg 329 flat plate or tank box systems), concentrating (eg compound parabolic) or employing 330 phase change materials. The working principle of an ICSSWH is shown in Figure 2 and 331 the key components and design considerations are:

- Collector inclination and orientation affects diurnal and seasonal variation of solar radiation incident on absorber surfaces and also affects natural convection and storage tank stratification.

- Transparent covers minimize convective (and some radiative) absorber heat losses and are essential for ICSSWH collectors designed to produce domestic hot water or to operate in cold and windy climates.

- Storage tank size, shape, \& configuration affect collection and retention efficiencies, stratification and achievable temperature. Tanks are usually heavily insulated on their non-absorbing sides to reduce heat loss.

- Fabrication material choices are the primary factor determining cost but also

Original academic works on ICSSWH technologies over the last decade have examined affect solar absorption and heat transfer characteristics (desired solar gains and unwanted losses), robustness and longevity. tank temperature stratification and draw-off mixing effects (Garnier et al., 2009; Borello et al., 2012); use of thermal diodes and concentrating reflectors to reduce heat loss (Souliotis et al., 2011\&2017; Smyth et al., 2015a\&b, 2017, 2018, 2019; Muhumuza et al., 2019a\&b and 2020); and use of phase-change thermal storage materials and heat pipes (Tarhan et al., 2006; Eames \& Griffiths, 2006; Chaabane, 2014; Bilardo et al., 2019). Studies by Krauter (2004) and Ziapour et al. (2014) examined the performance (respectively through experimental and simulation work) of novel PV-ICSSWH devices and identified a dearth of published work on similar concepts. Facade integration of PV-ICSSWH units (Pugsley et al., 2016 \& 2017; Smyth et al., 2019) has potential to increase available solar collection area, save floor space, reduce parasitic pumping energy requirements, and reduce material costs, but presents a number of practical challenges such as imposed structural loadings and maintenance access arrangements (considered in more detail in Part 2 of 2). 


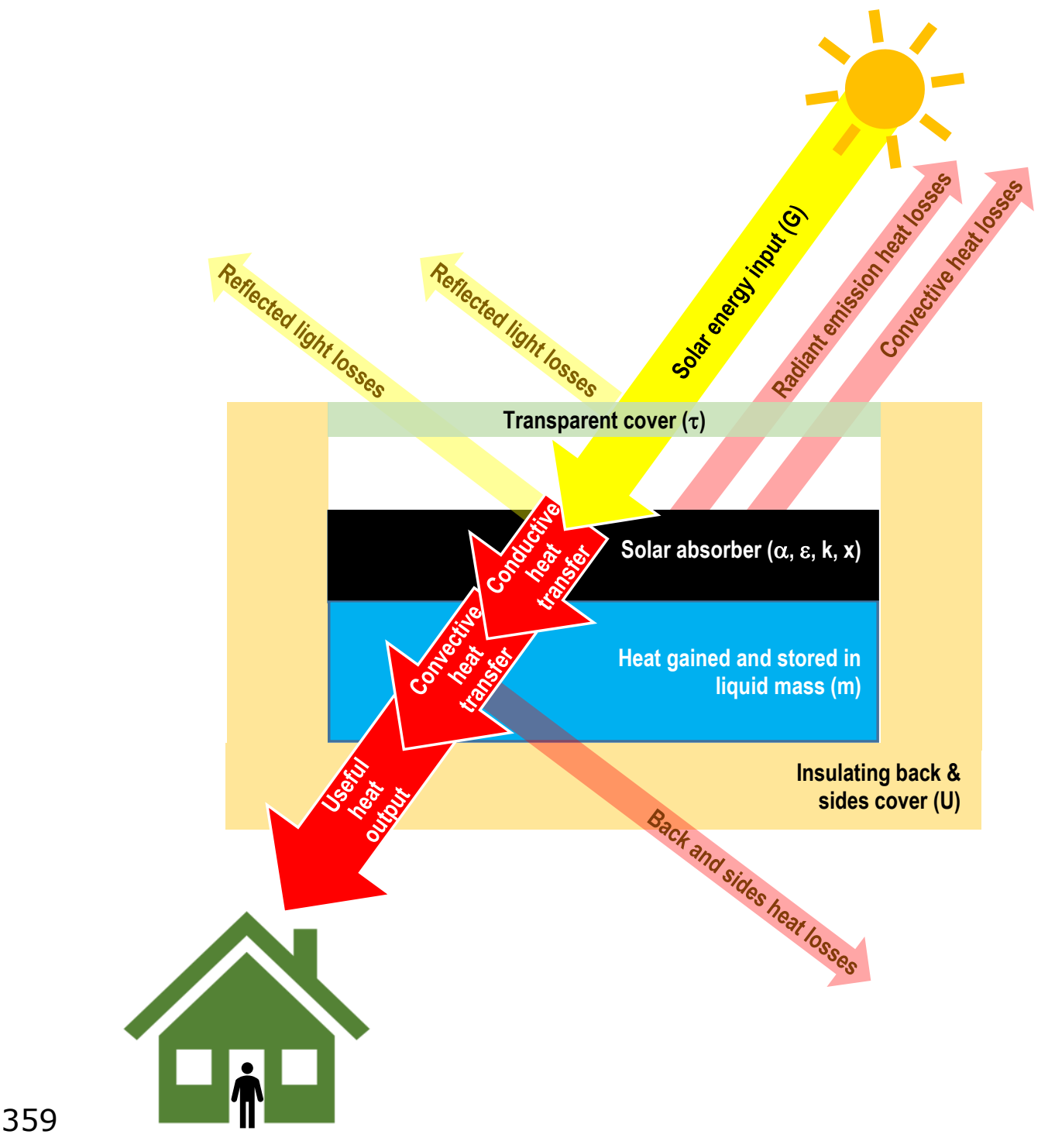

Figure 2: Energy conversion and loss mechanisms in ICSSWH

362 Almost all ICSSWH collectors feature some form of transparent cover because 363 overnight tank heat losses from uncovered absorbers would result in unacceptably low 364 morning-time tank temperatures. Solutions such as double covers, thermal diodes, or 365 heat pipes need to be considered for ICSSWH systems designed to produce domestic 366 hot water when operating in cold and windy climates. The volume-to-absorber area 367 ratio $(\mathrm{u} / \mathrm{A})$ is an important consideration in ICSSWH design as this determines the rate 368 at which the tank gains heat from the incident sunlight during collection periods and 369 also the rate at which heat is lost from the absorber to the ambient environment during 370 retention periods (cloudy or overnight). Storage tank shape can significantly affect the 371 solar collection and heat retention performances (owing to its influence on absorber 372 orientation and exposure; thermal stratification; and overall heat loss coefficients) as 373 well as physical robustness and aesthetics. In particular, tall tanks tend to promote 374 stratification (which maximises potential heat delivery temperatures); triangular and 
375 trapezoidal shapes enable inherent tilting of absorber surfaces (to align with the sun);

376 whilst cylindrical tanks offer inherent passive single-axis solar tracking and tend to be 377 more robust than cubic tanks. Tank envelopes must support the weight of water 378 contained within them and be able to withstand thermal expansion pressures (sealed 379 units/systems) and any externally imposed hydraulic pressures (from mains water or 380 raised header feed tanks). Tanks must be insulated to minimise heat loss from the 381 back and sides (those not used to absorb solar heat) but the insulation thickness can 382 add significantly to overall size. Smyth et al. (2006) and Singh et al. (2016) cite 383 numerous ICSSWH collector examples featuring single or multiple cylindrical, cuboid, 384 triangular, trapezoidal and pyramid tanks with volume-to-absorber area ratios in the 385 range $0.05<\mathrm{u} / \mathrm{A}<0.3 \mathrm{~m}^{3} / \mathrm{m}^{2}$ with $0.1 \mathrm{~m}^{3} / \mathrm{m}^{2}$ being a typical tank size. Small volumes 386 of stored water cause large diurnal temperature fluctuations in solar heating systems. 387 Larger volumes reduce fluctuation magnitudes thereby reducing summertime 388 overheating and wintertime freezing risks, but the resulting reduced maximum 389 temperatures can increase legionella risks. Schmidt \& Goetzberger (1990) suggest $390 \mathrm{u} / \mathrm{A}>0.07 \mathrm{~m}^{3} / \mathrm{m}^{2}$ for Northern European climates to reduce freeze risks. Amerongen et 391 al. (2013) suggests limiting criteria of $u / A<0.03 \mathrm{~m}^{3} / \mathrm{m}^{2}$ and $u / A<0.06 \mathrm{~m}^{3} / \mathrm{m}^{2}$ for 392 northern and southern European climates respectively in respect of controlling 393 legionella risk in direct-flow solar water heating systems. Using ICSSWH principles in 394 the context of BIPV/T presents an opportunity to prevent damagingly high stagnation 395 temperatures without the need for heat rejection equipment and offers significant 396 potential benefits in terms of reducing parasitic energy consumption for fluid pumping. 397 Such systems should be designed as indirect-flow types which employ heat exchangers 398 to mitigate legionella risk.

\section{$3992.5 \quad$ Solar thermal collection and heat retention behaviour}

400 The thermal power output $\left(\mathrm{q}_{\mathrm{T}}\right.$ ) of solar thermal collectors is conventionally represented 401 in the Hottel-Whillier-Bliss form (Equation 7) and presented in the form of efficiency 402 curves (see Figure 3) where the $\mathrm{X}$-axis is the solar thermal condition ( $\mathrm{N}$ according to 403 Equation 8) and the $y$-axis is the instantaneous solar thermal collection efficiency $\left(\eta_{T}\right.$ 404 according to Equation 9). On such plots, the y-axis intercept indicates maximum solar 405 thermal efficiency under zero heat loss conditions $\left(\eta_{T}=F \cdot \tau \cdot \alpha\right.$ where $\left.\mathrm{T}_{3}-\mathrm{T}_{\mathrm{a}}=0\right)$; the line 406 gradient $\left(F \cdot U_{L}\right)$ represents the overall heat loss coefficient referenced to the absorber 407 area $\left(A_{1}\right)$; and the $x$-axis intercept indicates the stagnation condition (maximum 408 achievable temperature for a given $\mathrm{N}$ when $\eta_{\mathrm{T}} \rightarrow 0$ and $\mathrm{T}_{3}=\mathrm{T}_{1}$ ). The $\mathrm{y}$-axis intercept is 409 sometimes referred to as the "optical efficiency" because many conventional solar 410 thermal collectors achieve near perfect absorber-to-fluid heat transfer under these 411 conditions $(\mathrm{F}>0.95)$ and overall efficiency is determined by the transmission- 
412 absorption product $(\tau \cdot \alpha)$. Heat removal factor $(F)$ describes the effectiveness of 413 absorber-to-tank heat transfer which can be expressed according to Equation 10. 414 Production of electricity reduces the amount of heat available for transfer into the tank 415 thus Equation 10 remains valid for the hypothetical scenario of $100 \%$ electrical 416 efficiency where $q_{E}=G \cdot A_{1}$ which would result in $F=0$.

$417 \quad q_{T}=F \cdot G \cdot A_{1}\left([\tau \cdot \alpha]-\left[U_{L} \frac{T_{3}-T_{a}}{G}\right]\right)$ Equation 7

$418 \quad N=\frac{T_{3}-T_{a}}{G}$ Equation 8

$419 \quad \eta_{T}=\frac{q_{T}}{G \cdot A_{1}}$ Equation 9

$420 \quad F=\frac{\text { Heat transferred }}{\text { Maximum heat available }}=\frac{q_{T}}{\left[\tau \cdot \alpha-\eta_{E}\right]^{\cdot} \cdot G \cdot A_{1}}$ Equation 10

421 $-q_{T}=U_{r, s y s} A_{r, s y s}\left(T_{3}-T_{a}\right)$

Equation 11

422

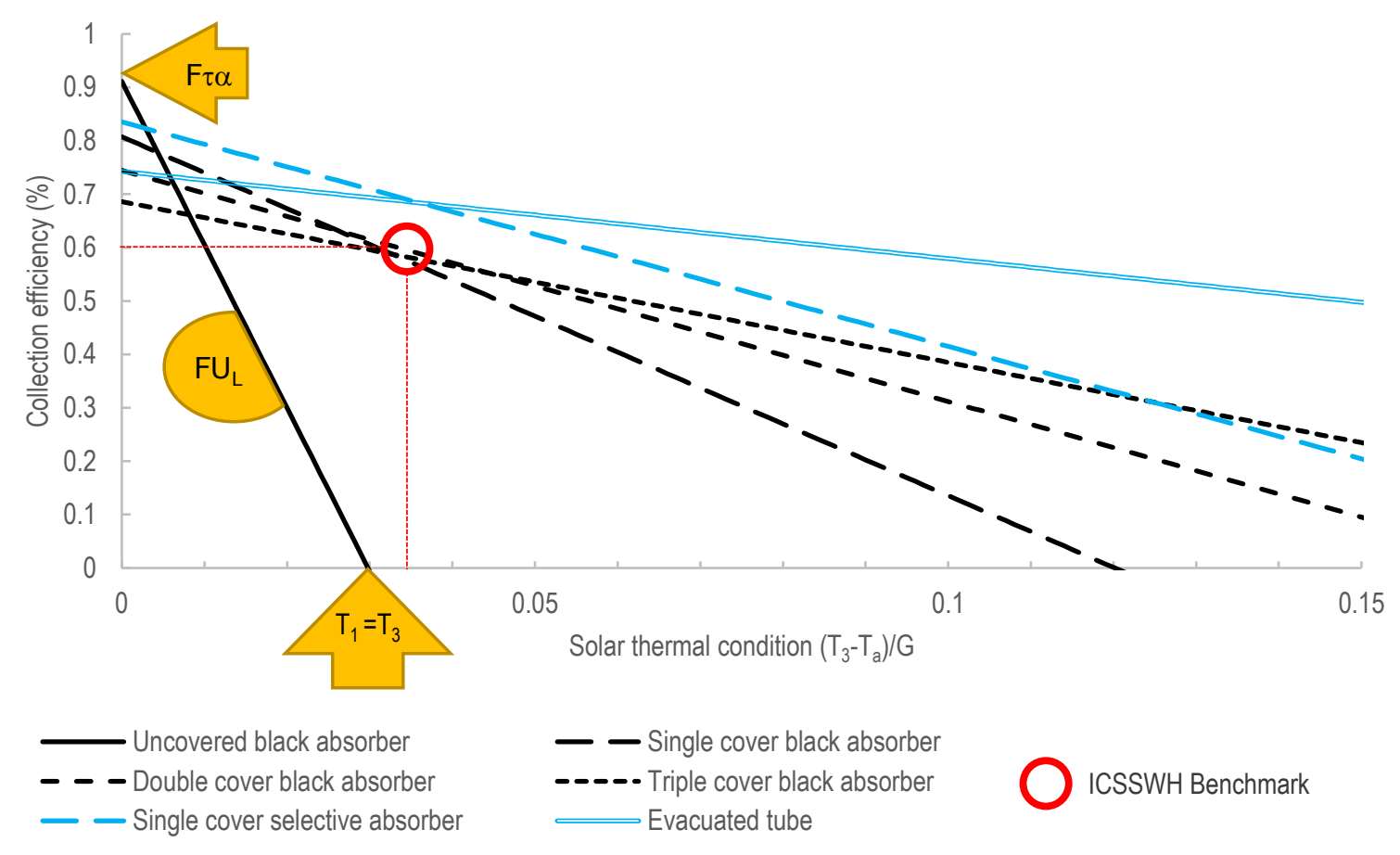

424 Figure 3: Typical solar collector performance characteristics (at $2 \mathrm{~m} / \mathrm{s}$ wind speed)

426 Equations 7-10 are only relevant when the collector is illuminated $(G>0)$. When the 427 ICSSWH is in darkness, the total heat loss $\left(-q_{T}\right)$ is determined by the overall heat loss 428 coefficient $\left(U_{\text {sys }}\right)$ referenced to the overall envelope heat loss area $\left(A_{\text {sys }}\right)$ and the 429 temperature difference between the tank and the ambient ( $\left.T_{3}-T_{a}\right)$ as expressed by 430 Equation 11 . The key difference between the collection and retention heat loss 
431 coefficients is that $U_{\text {sys }}$ describes the total heat loss from the storage tank assuming 432 that it emanates from the whole envelope $\left(A_{\text {sys }}\right)$ whereas $U_{L}$ describes the total heat 433 loss from the storage tank assuming that it emanates from the absorber $\left(A_{1}\right)$ which is 434 separated from the storage tank by heat removal factor $F$. The effective heat loss area 435 can be taken as approximately equal to the absorber area $\left(\mathrm{A}_{\text {sys }} \approx \mathrm{A}_{1}\right)$ if the storage tank 436 and sides of the collector are highly insulated or approximately equal to the whole 437 envelope area $\left(A_{\text {sys }} \approx A_{1}+A_{3 i}\right)$ if the insulation of the storage tank and sides has similar 438 performance characteristics as the transparent cover. It is difficult to determine a 439 sensible value for $A_{\text {sys }}$ in other less definite cases.

440 In the case of conventional solar thermal collectors where heat is extracted and 441 delivered by a continuous fluid flow, the thermal power gain can be determined through 442 steady state testing based upon the mass flow rate, specific heat capacity, and inlet443 to-outlet temperature difference $\left(q_{T}=m \cdot c_{p} \cdot \Delta T_{\text {out-in }}\right)$. However, in the case of ICSSWH 444 devices, there is commonly no fluid flow during solar collection periods and thus steady 445 state conditions rarely occur (except in the very unusual case where a concurrent heat 446 demand exactly matches solar heat collection). Instead, the thermal power gained by 447 an ICSSWH is usually determined using either quasi steady-state or whole-day testing 448 based upon the rate of temperature rise of the stored thermal mass $\left(q_{T}=M \cdot c_{p} \cdot \Delta T_{3} / t_{\text {col }}\right)$. 449 Equation 12 defines the total insolation $\left(\mathrm{H}_{\mathrm{col}}\right)$ during the collection period $\left(\mathrm{t}_{\mathrm{col}}\right)$ to enable 450 determination of daily average solar thermal efficiency $\left(\eta_{T, c o l}\right)$ according to 451 Equation 13. The ability of an ICSSWH collector to retain stored heat for a period of 452 time ( $t_{\text {ret }}$ ) when no solar resource is available (eg at night when $\mathrm{G} \approx 0$ ) can be quantified 453 in terms of heat retention efficiency ( $\eta_{T, \text { ret }}$ according to Equation 14 ) which is defined 454 as the ratio of thermal energy in the tank at the end of the retention period $\left(t=t_{\text {col }}+t_{\text {ret }}\right)$ 455 divided by the thermal energy in the tank at the start of the retention period $\left(t=t_{\text {col }}\right)$. 456 Collection periods are chosen to represent specific latitudinal and seasonal 457 circumstances but are commonly taken as 6,8 or $12 \mathrm{hrs}$ ( $\mathrm{t}_{\mathrm{col}}=21600,28800$ or $43200 \mathrm{~s}$ ) 458 with corresponding retention periods of 18,16 or $12 \mathrm{hrs}$ ( $\mathrm{t}_{\text {ret }}=64800,57600$ or 459 43200s). Energy contained in the tank at a given time $\left(Q_{\mathrm{T}[t]}\right)$ is determined by the 460 product of its heat capacity $\left(M \cdot c_{p}\right)$ and temperature $\left(T_{3[t]}\right)$ normalised to respective 461 ambient temperatures at the end of the preceding collection period $\left(T_{a\left[t_{c o l}\right]}\right)$ and 462 averaged throughout the retention period $\left(\widetilde{T}_{a\left[t_{r e t}\right]}\right)$. Retention efficiency can be used to 463 determine an overall reverse mode heat transfer coefficient $\left(U_{r, s y s} A_{s y s}\right.$ according to 464 Equations 15) which describes heat lost across the tank-to-ambient temperature 465 difference $\left(T_{3\left[t=t_{c o l}\right]}-\widetilde{T}_{a\left[t_{r e t}\right]}\right)$. A corresponding overall forward mode heat transfer 
coefficient can be defined ( $U_{f, s y s} A_{s y s}$, according to Equation 16) to describe heat loss across the tank-to-ambient temperature difference during collection periods $\left(T_{3\left[t=t_{c o l}\right]}-\right.$

$\left.468 \tilde{T}_{a\left[t_{c o l}\right]}\right)$. Dynamic modelling of heat loss during retention periods $\left(-\Delta Q_{T\left[t_{r e t}\right]}\right)$ and heat 469 gained during collection periods $\left(\Delta Q_{T\left[t_{c o l}\right]}\right)$ can be performed using Equations 17 and 18 470 which are essentially the inverse forms of Equations 15 and 16.

$471 \quad H_{c o l}=\int_{\mathrm{t}=0}^{\mathrm{t}=\mathrm{t}_{\mathrm{col}} \mathrm{G}}$

Equation 12

$472 \quad \eta_{T, \mathrm{col}}=\frac{\text { Energy in store at } t=t_{\text {col }}}{\text { Energy incident from } t=t_{0} \text { to } t=t_{\text {col }}}=\frac{M \cdot c_{p}\left(T_{3\left[t=t_{c o l}\right]}-T_{3\left[t=t_{0}\right]}\right)}{H_{c o l} \cdot A_{1}}$ Equation 13

$473 \quad \eta_{T, r e t}=\frac{\text { Retained energy in store at } t=t_{c o l}+t_{r e t}}{\text { Energy in store at } t=t_{c o l}}=\frac{M \cdot c_{p}\left(T_{3\left[t=t_{c o l}+t_{r e t}\right]}-\tilde{T}_{a\left[t_{r e t}\right]}\right)}{M \cdot c_{p}\left(T_{3\left[t=t_{c o l}\right]}-T_{a\left[t=t_{c o l}\right]}\right)}$ Equation 14 474 $U_{r, s y s} A_{s y s}=\frac{M \cdot c_{p}}{t_{r e t}} \ln \left(\frac{1}{\eta_{T, r e t}}\right)$ Equation 15

$-\Delta Q_{T\left[t_{r e t}\right]}=Q_{T\left[t=t_{c o l}\right]} \frac{T_{3\left[t=t_{c o l}\right]}-\tilde{T}_{a\left[t_{r e t}\right]}}{T_{3\left[t=t_{c o l}\right]}-T_{a\left[t=t_{c o l}\right]}}\left(1-\left[e^{\frac{U_{r, s y s} A_{s y s} t_{r e t}}{M \cdot c_{p}}}\right]^{-1}\right)$

$\Delta Q_{T\left[t_{c o l}\right]}=F \cdot A_{1}\left(H_{c o l} \cdot \tau \cdot \alpha-t_{c o l} U_{L}\left(T_{3\left[t=t_{0}\right]}-T_{a\left[t=t_{0}\right]}\right)\right)\left[e^{\frac{F \cdot U_{L} A_{1} t_{c o l}}{M \cdot c_{p}}}\right]^{-1}$

478 Heat could feasibly be drawn from the ICSSWH to serve a variety of thermal load 479 demands at different times of the day (eg morning or evening bathing, space heating 480 at night, etc). If all available heat is consumed during a single short duration draw-off 481 event occurring once every $24 \mathrm{~h}$, the maximum availability of stored heat $\left(\mathrm{Q}_{\mathrm{T}, 24 \max }\right.$, 482 Equation 19) occurs when the tank temperature reaches its maximum (near the end 483 of the collection period, usually just before dusk) and minimum availability of stored 484 heat $\left(\mathrm{Q}_{T, 24 \mathrm{~min}}\right.$, Equation 20) coincides with the time when the lowest tank temperature 485 occurs (near the end of the retention period, usually around dawn). Provided that $t_{\text {col }}$ 486 and $t_{\text {ret }}$ cover a contiguous $24 \mathrm{~h}$ period then the product of the collection and retention 487 efficiencies can reasonably be described as the diurnal thermal efficiency, where $488 \eta_{T, 24}=1$ if all available solar energy incident during $t_{c o l}$ is collected and then retained 489 without loss for the duration of $t_{\text {ret, }}$ or $\eta_{T, 24}=0$ if no heat was collected or all collected 490 heat was lost. The total diurnal efficiency $\left(\eta_{T+E, 24}\right)$ is the sum of the diurnal thermal 491 efficiency and the diurnal electrical efficiency $\left(\eta_{E, 24}\right)$ and can be defined according to 
492 Equation 21. It is important to note that diurnal thermal efficiency (by this definition)

493 is a relative measure of long-term performance and that non-zero values do not 494 necessarily imply net heat gain in a given $24 \mathrm{~h}$ period. For example, heat gained on a 495 cloudy day following several warm sunny days could well be less than the amount of 496 heat lost during a subsequent cool night, even with relatively high collection, retention 497 and diurnal thermal efficiencies.

$498 Q_{T, 24 \max }=\eta_{T, \text { col }} \cdot \mathrm{A}_{1} \cdot H_{c o l}$ Equation 19

$499 Q_{T, 24 \min }=\eta_{T, \text { col }} \cdot \eta_{T, \text { ret }} \cdot \mathrm{A}_{1} \cdot H_{\text {col }}$

Equation 20

$500 \quad \eta_{T+E, 24}=\eta_{T, 24}+\eta_{E, 24}=\eta_{T, \text { col }} \cdot \eta_{T, r e t}+\frac{1}{t_{c o l}} \int_{t=0}^{t=t_{c o l}} \frac{q_{E}}{G \cdot A_{1}}$

Equation 21

501 Table 2 summarises performance values reported in previous experimental studies on 502 ICSSWH collector prototypes to serve as benchmarks for the devices examined in this 503 and future studies. A confusing variety of metrics and test methodologies are reported 504 in the literature, but most can be readily interpreted and converted into $\eta_{T, \text { col }}, \eta_{T, \text { ret }}$, 505 and $U_{r, s y s} A_{s y s}$ parameters according to the definitions given above. It is important to 506 ensure that the solar thermal condition is properly accounted for when comparing 507 reported collection efficiencies because $\eta_{T, c o l}$ inherently reduces with increasing $\mathrm{N}$. Test 508 duration and tank-to-ambient temperature difference must be borne in mind when 509 comparing retention efficiencies because $\eta_{T, r e t}$ inherently reduces with increasing tret $_{\text {ret }}$ 510 and $\Delta T_{3 a}$. Likewise, comparisons between heat loss coefficients must be made with 511 caution because there is a lack of consistency concerning definitions for reference areas 512 (these are variably reported based on the absorber, aperture, or whole envelope area) 513 and because $U_{s y s} A_{s y s}$ inherently increases in proportion to the physical size of the 514 ICSSWH. To enable fair comparisons in relation to heat retention performance, we 515 propose two new heat loss coefficient metrics, one of which is referenced to stored 516 water volume $\left(U_{r, \text { sys }} A_{\text {sys }} / u\right)$ and the other of which is referenced to the effective aperture 517 area $\left(U_{r, \text { sys }} A_{s y s} / A_{1}\right)$. The latter has the advantage of being broadly equivalent to $F \cdot U_{L}$ 518 values reported for conventional solar water heating collectors whereas the former is 519 very useful when drawing comparisons between ICSSWH collectors with very different 520 storage tank sizes and shapes. It should be noted that the data reported in Table 2 is 521 drawn from a variety indoor and outdoor tests for which the influences of variables 522 such as wind speed (which affects heat losses) and solar incidence angle (which affects 523 optical losses) cannot easily be determined. Data in Table 2 suggests a state-of-the524 art benchmark ICSSWH collection efficiency of $\eta_{T, c o l} \approx 60 \%$ at $\mathrm{N} \approx 0.035 \mathrm{~m}^{2} \mathrm{~K} \cdot \mathrm{W}^{-1}$ 
525 (comparable to efficiencies achieved by basic conventional solar thermal collectors, 526 refer to Figure 3) and state-of-the-art benchmark heat loss coefficients of $527 \mathrm{U}_{\mathrm{r}, \mathrm{sys}} \mathrm{A}_{\mathrm{sys}} / \mathrm{A}_{1} \approx 1 \mathrm{~W} \cdot \mathrm{m}^{-2} \mathrm{~K}^{-1}$ and $\mathrm{U}_{\mathrm{r}, \mathrm{sys}} \mathrm{A}_{\mathrm{sys}} / \mathrm{u} \approx 10 \mathrm{~W} \cdot \mathrm{m}^{-3} \cdot \mathrm{K}^{-1}$ at $\Delta \mathrm{T}_{3 \mathrm{a}} \approx 25^{\circ} \mathrm{C}$ (equivalent to a $528100 \mathrm{~L}$ cube shaped tank fully insulated on all sides with $30 \mathrm{~mm}$ insulation of conductivity $\left.529 \mathrm{k}=0.025 \mathrm{~W} \cdot \mathrm{m}^{-1} \mathrm{~K}^{-1}\right)$.

531 Table 2: Performances of ICSSWH collectors reported in the literature

\begin{tabular}{|c|c|c|c|c|c|c|c|c|}
\hline \multirow{3}{*}{ ICSSWH description } & $\begin{array}{c}\text { Solar } \\
\text { thermal } \\
\text { collection } \\
\text { efficiency }\end{array}$ & $\begin{array}{c}\text { Over- } \\
\text { night heat } \\
\text { retention } \\
\text { efficiency }\end{array}$ & $\begin{array}{c}\text { Test } \\
\text { duration }\end{array}$ & $\begin{array}{c}\text { Overall } \\
\text { heat loss } \\
\text { coefficient }\end{array}$ & $\begin{array}{c}\text { Effective } \\
\text { aperture } \\
\text { area }\end{array}$ & $\begin{array}{c}\text { Water } \\
\text { storage } \\
\text { vessel } \\
\text { volume } \\
\end{array}$ & $\begin{array}{c}\text { Aperture } \\
\text { specific } \\
\text { heat loss } \\
\text { coefficient }\end{array}$ & $\begin{array}{c}\text { Volume } \\
\text { specific } \\
\text { heat loss } \\
\text { coefficient }\end{array}$ \\
\hline & $\eta_{T, c o l}$ & $\eta_{T, r e t}$ & $\begin{array}{l}t_{c o l} \\
+t_{r e t}\end{array}$ & $U_{r, s y s} A_{s y s}$ & $A_{1}$ & $\boldsymbol{u}$ & $\frac{U_{r, s y s} A_{s y s}}{A_{1}}$ & $\frac{U_{r, s y s} A_{s y s}}{u}$ \\
\hline & $(\%)$ & $(\%)$ & (hours) & $\left(W \cdot K^{-1}\right)$ & $\left(\mathrm{m}^{2}\right)$ & $(\mathrm{L})$ & $\left(\mathrm{W} \cdot \mathrm{m}^{2} \mathrm{~K}^{-1}\right)$ & $\left(\mathrm{W} \cdot \mathrm{m}^{3} \mathrm{~K}^{-1}\right)$ \\
\hline $\begin{array}{l}\text { Near-triangular trapezoidal prism tank, } \\
\text { single glazed, } 25 \mathrm{~mm} \text { insulation. } \\
\text { Thermosiphonically coupled absorber } \\
\text { channel, thermal diode reverse flow stop } \\
\text { valve. (Mohamad, 1997) }\end{array}$ & $53^{*}$ & 66 & $12+12$ & $4^{*}$ & 0.55 & 100 & $7.3^{*}$ & $40^{*}$ \\
\hline $\begin{array}{l}\text { Semi-flat trapezoidal tank, double (?) } \\
\text { glazed, } 50 \mathrm{~mm} \text { insulation. } \\
\text { Thermosiphonically coupled absorber } \\
\text { channel, thermal diode reverse flow stop } \\
\text { valve. (Faiman et al., 2001) }\end{array}$ & 34 & 84 & $11+8.5$ & 2.8 & 1.15 & 120 & 2.4 & 23 \\
\hline $\begin{array}{l}\text { Horizontal cylindrical tank, two-part CPC } \\
\text { reflector, single glazed. } \\
\text { (Tripanagnostopoulos et al., 2002) } \\
\quad \text { STS-1A \& 2A: Single tank } \\
\text { STS-1B \& 2B: Modified reflector } \\
\text { DTS-2B: Double tanks, modified reflector }\end{array}$ & $\begin{array}{l}41 \\
48 \\
50 \\
\end{array}$ & $\begin{array}{l}58 \\
57 \\
50 \\
\end{array}$ & $\begin{array}{l}12+12 \\
12+12 \\
12+12 \\
\end{array}$ & $\begin{array}{l}5.3 \\
5.5 \\
6.7 \\
\end{array}$ & $\begin{array}{l}0.95 \\
0.95 \\
0.95\end{array}$ & $\begin{array}{l}100 \\
100 \\
100 \\
\end{array}$ & $\begin{array}{l}5.6 \\
5.8 \\
7.1 \\
\end{array}$ & $\begin{array}{l}53 \\
55 \\
67 \\
\end{array}$ \\
\hline $\begin{array}{l}\text { Cylindrical tank, selective coating, two- } \\
\text { part CPC reflector, single glazed, } \\
\text { insulated. (Smyth et al., 2003) } \\
\text { A2: Basic design } \\
\text { A4: Internal perforated sleeve added } \\
\text { A8: extra insulation added }\end{array}$ & $\begin{array}{l}52 \\
58 \\
59 \\
\end{array}$ & $\begin{array}{l}45 \\
53 \\
61 \\
\end{array}$ & $\begin{array}{l}8+16 \\
8+16 \\
8+16 \\
\end{array}$ & $\begin{array}{c}4.2 \\
3.4 \\
4 \\
\end{array}$ & $\begin{array}{l}0.92 \\
0.92 \\
0.92 \\
\end{array}$ & $\begin{array}{l}57 \\
57 \\
85 \\
\end{array}$ & $\begin{array}{l}4.6 \\
3.7 \\
4.3 \\
\end{array}$ & $\begin{array}{l}74 \\
60 \\
47 \\
\end{array}$ \\
\hline $\begin{array}{c}\text { Close-coupled tubular absorber on top of } \\
\text { a flat cuboid tank with bulbous head. } \\
\text { Tank fully enclosed with } 40 \mathrm{~mm} \text { insulation. } \\
\text { (Sopian et al., 2004) } \\
\text { 1: Free thermosiphonic flow } \\
\text { 2: Thermal diode reverse flow stop valve }\end{array}$ & $\begin{array}{l}45 \\
45 \\
\end{array}$ & $\begin{array}{l}18 \\
52 \\
\end{array}$ & $\begin{array}{l}8+16 \\
8+16 \\
\end{array}$ & $\begin{array}{l}40.9 \\
15.6 \\
\end{array}$ & $\begin{array}{l}2.30 \\
2.30 \\
\end{array}$ & $\begin{array}{l}329 \\
329 \\
\end{array}$ & $\begin{array}{c}17.8 \\
6.8 \\
\end{array}$ & $\begin{array}{c}124 \\
47 \\
\end{array}$ \\
\hline $\begin{array}{l}\text { Double horizontal cylindrical tanks, three- } \\
\text { part CPC reflector, single glazed, } \\
\text { insulated. Tripanagnostopoulos \& } \\
\text { Souliotis (2006) } \\
\text { DTS-B2 reflector design variant } \\
\text { DTS-C2 reflector design variant }\end{array}$ & $\begin{array}{l}55 \\
46 \\
\end{array}$ & $\begin{array}{l}53 \\
59 \\
\end{array}$ & $\begin{array}{l}12+12 \\
12+12 \\
\end{array}$ & $\begin{array}{l}6.5 \\
5.5 \\
\end{array}$ & $\begin{array}{l}1.01 \\
0.75 \\
\end{array}$ & $\begin{array}{l}107 \\
107 \\
\end{array}$ & $\begin{array}{l}6.4 \\
7.3 \\
\end{array}$ & $\begin{array}{l}61 \\
51 \\
\end{array}$ \\
\hline $\begin{array}{l}\text { Horizontal cylindrical tank-in-tank, } \\
\text { selective coating, two-part CPC reflector, } \\
\text { single glazed, insulated. Air-filled annulus. } \\
\text { (Souliotis et al., 2011) }\end{array}$ & 33 & 66 & $12+12$ & 1.5 & 0.83 & 44 & 1.8 & 34 \\
\hline
\end{tabular}




\begin{tabular}{|c|c|c|c|c|c|c|c|c|}
\hline $\begin{array}{l}\text { Cuboid tank, selective coating on } \\
\text { underside, 50mm insulation elsewhere. } \\
\text { Single glazed aperture with reflectors } \\
\text { (1.8x CPC, reverse circular \& straight) } \\
\text { directing light onto inverted absorber. } \\
\text { (Smyth et al., 2005) } \\
\text { 1: No baffles in reflector } \\
\text { 2: Two full-width transparent baffles } \\
\text { 7: One half-width transparent baffle }\end{array}$ & $\begin{array}{l}43 \\
40 \\
46 \\
\end{array}$ & $\begin{array}{l}86 \\
92 \\
85 \\
\end{array}$ & $\begin{array}{l}8+16 \\
8+16 \\
8+16 \\
\end{array}$ & $\begin{array}{l}0.81 \\
0.45 \\
0.84 \\
\end{array}$ & $\begin{array}{l}0.36 \\
0.36 \\
0.36 \\
\end{array}$ & $\begin{array}{l}38 \\
38 \\
38 \\
\end{array}$ & $\begin{array}{l}2.3 \\
1.3 \\
2.3 \\
\end{array}$ & $\begin{array}{l}21 \\
12 \\
22 \\
\end{array}$ \\
\hline $\begin{array}{l}\text { Horizontal cylindrical tank, selective } \\
\text { coating, two-part CPC reflector, glazed, } \\
\text { insulated. (Souliotis et al., 2013) } \\
\text { 3A: Single glazing } \\
\text { 3B: Double glazing }\end{array}$ & $\begin{array}{l}54 \\
53 \\
\end{array}$ & $\begin{array}{l}61 \\
65 \\
\end{array}$ & $\begin{array}{l}12+12 \\
12+12 \\
\end{array}$ & $\begin{array}{c}4.85 \\
4.2 \\
\end{array}$ & $\begin{array}{l}1.48 \\
1.48 \\
\end{array}$ & $\begin{array}{l}102 \\
102 \\
\end{array}$ & $\begin{array}{l}3.3 \\
2.8 \\
\end{array}$ & $\begin{array}{l}48 \\
41 \\
\end{array}$ \\
\hline $\begin{array}{l}\text { Horizontal cylindrical tank-in-tank, } \\
\text { selective coating, two-part CPC reflector, } \\
\text { single glazed, insulated. Evacuated } \\
\text { annulus part-filled with water to form a } \\
\text { thermal diode (Souliotis et al., 2017) } \\
\text { Starting pressure } 86 \mathrm{mbar} \\
\text { Starting pressure } 998 \mathrm{mbar}\end{array}$ & $\begin{array}{l}29 \\
31 \\
\end{array}$ & $\begin{array}{l}74 \\
68 \\
\end{array}$ & $\begin{array}{l}12+12 \\
12+12 \\
\end{array}$ & $\begin{array}{l}1.29 \\
1.66 \\
\end{array}$ & $\begin{array}{l}0.83 \\
0.83 \\
\end{array}$ & $\begin{array}{l}44 \\
44 \\
\end{array}$ & $\begin{array}{l}1.6 \\
2.0 \\
\end{array}$ & $\begin{array}{l}29 \\
38 \\
\end{array}$ \\
\hline $\begin{array}{l}\text { Vertical cylindrical tank-in-tank, matt } \\
\text { black, transparent plastic cylindrical } \\
\text { cover, insulated ends. Evacuated annulus } \\
\text { (38mbar) with pumped thermal diode. } \\
\text { (Smyth et al., 2018) }\end{array}$ & $36^{*}$ & 61 & $6+18$ & 0.9 & 0.32 & 28 & 2.9 & 32 \\
\hline $\begin{array}{l}\text { Horizontal cylindrical tank-in-tank, matt } \\
\text { black, transparent plastic cylindrical } \\
\text { cover, insulated ends. Evacuated annulus } \\
\text { part-filled with water to form a thermal } \\
\text { diode (Muhumuza et al., 2019) } \\
\text { 1: Aluminium outer vessel, no capillary } \\
\text { 2: Stainless steel outer vessel + capillary } \\
\text { 3: As variant } 2 \text { but longer vessels }\end{array}$ & $\begin{array}{l}28^{*} \\
31^{*} \\
29^{*}\end{array}$ & $\begin{array}{l}25 \\
40 \\
48 \\
\end{array}$ & $\begin{array}{l}6+18 \\
6+18 \\
6+18\end{array}$ & $\begin{array}{c}1.5 \\
1 \\
1.3 \\
\end{array}$ & $\begin{array}{l}0.24 \\
0.24 \\
0.40 \\
\end{array}$ & $\begin{array}{l}17 \\
17 \\
28 \\
\end{array}$ & $\begin{array}{l}6.1 \\
4.1 \\
3.2 \\
\end{array}$ & $\begin{array}{l}88 \\
59 \\
46 \\
\end{array}$ \\
\hline $\begin{array}{l}\text { Horizontal rectangular tank, matt black, } \\
\text { insulated on } 5 \text { sides with double glazed } \\
\text { cover (Harmim (2019) }\end{array}$ & 47 & 93 & $12+12$ & 2.6 & 1.13 & 60 & 2.3 & 43 \\
\hline $\begin{array}{l}\text { Benchmarks } \\
\text { Minimum reported in literature } \\
\text { Average reported in literature } \\
\text { Maximum reported in literature } \\
\text { Targets for ICSSWH development }\end{array}$ & $\begin{array}{l}28 \\
43 \\
59 \\
60\end{array}$ & & & & & & $\begin{array}{c}1.3 \\
4.6 \\
17.8 \\
1.0\end{array}$ & $\begin{array}{c}12 \\
49 \\
124 \\
10\end{array}$ \\
\hline
\end{tabular}

Collection efficiencies reported in the table relate to an average daily solar thermal condition of $\mathrm{N}=0.035 \pm 0.005 \mathrm{~m}^{2} \mathrm{~K} \cdot \mathrm{W}^{-1}$. Retention efficiencies and heat loss coefficients reported in the table relate to a normalised stored water temperature of $\Delta T_{3 a}=25 \pm 10^{\circ} \mathrm{C}$ (averaged over the retention period). Exceptions where data relates to $\mathrm{N} \approx 0.01 \mathrm{~m}^{2} \mathrm{~K} \cdot \mathrm{W}^{-1}$ and $\Delta \mathrm{T}_{3 \mathrm{a}} \approx 10^{\circ} \mathrm{C}$ are marked with asterisk ${ }^{*}$. Reported values of $\mathrm{A}_{1}$ relate to the transparent aperture area (excluding external framing elements) which is typically the same as the absorber area for non-concentrating ICSSWH devices.

$537 \quad 2.6 \quad$ Planar Liquid-Vapour Thermal Diodes

538 A thermal diode is a unidirectional heat transfer device that operates in a manner 539 analogous to an electrical semiconductor diode by offering low resistance (thermal 540 conductance) in one direction and high resistance (thermal insulation) in the other.

541 Thermal diode devices have been used to successfully reduce heat loss via reverse flows

542 in thermosiphonic solar water heaters (one-way valves employed by Mohamad, 1997;

543 Faiman et al., 2001; Sopian et al., 2004), to promote stratification in hot water storage 544 tanks (Smyth et al., 1999 and Rhee et al., 2010), and to reduce overnight heat losses 545 from ICSSWH absorbers (De Beijer, 1998; Quinlan, 2010; Souliotis et al., 2011\&2017; 
546 Smyth et al., 2015a\&b, 2017, 2018, 2019; Pugsley et al., 2016 \& 2017; Muhumuza et 547 al., 2019a\&b and 2020).

548 Planar Liquid-Vapour Thermal Diodes (PLVTD) consist of two parallel plates of area $549 A=y z$ separated by a cavity of depth $x$ which contains a quantity of working fluid 550 maintained in a thermodynamic state close to saturation (Pugsley et al., 2019 \& 2020).

551 During forward mode operation, wetting of the hottest plate (evaporator) through 552 contact with the liquid working fluid generates vapour, which then migrates to the 553 colder plate (condenser) where it releases its latent heat and generates condensate to 554 complete the cycle. During reverse mode operation, the hottest plate is kept dry so 555 that no vapour can be generated, no latent heat transfer occurs, and the partially 556 evacuated cavity acts as an insulator (see Figure 4). Requirements, functions and 557 interactions of the main PLVTD components can be summarised as follows, based on 558 Pugsley et al. (2017 \& 2020):

559 - Evaporator and condenser plates should be formed of thermally conductive 560 material and should be as thin as possible to maximise forward mode heat 561 transfer. Choice of plate thickness is also governed by the inherent need to 562 prevent structural deformation caused by implosion forces associated with the 563 combination of cavity vacuum and external atmospheric pressure. Internal 564 supporting structure is generally required in large PLVTDs. Hermetic sealing is 565 required to prevent infiltration of non-condensable gases.

566 - Cavity sidewalls and internal structure should have low thermal 567 conductivity to minimise bridging that would otherwise cause unwanted reverse 568 mode heat transfer. These elements must provide sufficient structural strength 569 to prevent deformation and should be formed of low-outgassing materials to 570 avoid risk of vacuum degradation (also applies to plates and seal materials). 571 Internal structures must not significantly impede vapour flows between the 572 plates in order to avoid impairing forward mode heat transfer.

573 - Working fluid selection considerations include saturation pressure at operating 574 temperature, specific heat capacity, liquid \& vapour thermal conductivities, 575 liquid \& vapour viscosities, latent heat of vaporisation, cost, flammability, 576 toxicity, global warming and ozone depletion potential. Water appears to be a 577 suitable fluid. Determination of required quantity involves consideration of plate 578 area, cavity volume, the need to minimise thermal inertia, and the need to avoid 579 evaporator dry-out at high temperatures. Working fluid reservoirs should be 580 designed to prevent thermal bridging between the plates. 

continuous and uniform working fluid flows during forward mode operation and should preferably maintain dry plates in reverse mode. Evaporator hydrophilicity and condenser hydrophobicity are important considerations. Evaporator wetting

\section{8} can be achieved by a variety of active (eg pumped falling film or spray) or

Experimental and theoretical work by Pugsley et al. (2016, 2017, 2019 \& 2020) demonstrated that large vertical PLVTDs $\left(A=0.98 \mathrm{~m}^{2}\right.$ and $x=70 \mathrm{~mm}$ deep) suitable for integration in façade mounted ICSSWH collectors can be realised to achieve reverse mode insulation of $\mathrm{U}_{\mathrm{r}}<2 \mathrm{~W} \cdot \mathrm{m}^{-2} \mathrm{~K}^{-1}$ and forward mode heat transfer in the range $50<\mathrm{U}_{\mathrm{f}}<900 \mathrm{~W} \cdot \mathrm{m}^{-2} \mathrm{~K}^{-1}$. Reverse mode insulation is determined by PLVTD dimensions such that thermal conductance decreases with increasing depth. Forward mode heat transfer is highly dependent upon PLVTD operating conditions such that thermal conductance increases with increasing temperature and increasing heat flux but is relatively insensitive to PLVTD dimensions.

Using a vertical PLVTD as the connecting element between PV cells and water storage tank in a BIPV-ICSSWH facade system has the potential to not only reduce ICSSWH heat losses by improving tank insulation, but also to improve thermal and electrical collection efficiencies by improving heat transfer. Given that PLVTDs essentially act as heat spreaders (Boreyko and Chen, 2013) there is also potential for electrical efficiency 603 improvements associated with improved PV cell temperature uniformity.

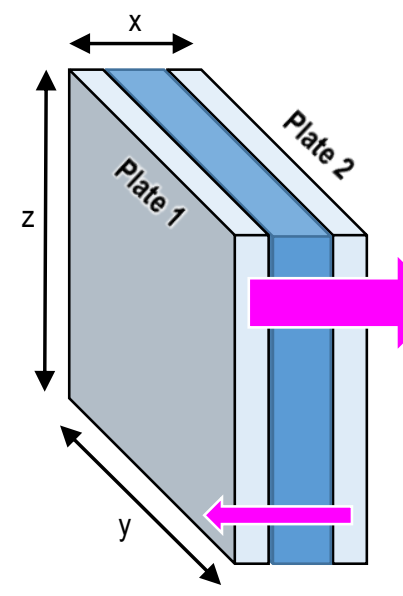

FORWARD MODE

Plate 1 wetted and hotter than Plate 2

Latent heat transfer from $1 \rightarrow 2$

\section{REVERSE MODE}

Plate 2 dry and hotter than Plate 1

No latent heat transfer from $2 \rightarrow 1$

(conduction and radiation only) 


\subsection{Energy balance model}

611 The fundamental physical arrangement of the BIPV-PLVTD-ICSSWH device proposed 612 in Figure 1 can be represented by the lumped parameter model shown in Figure 5 and 613 the equivalent resistance network shown in Figure 6. The model describes how the 614 input solar flux (G) is absorbed by the PV cells (at temperature $T_{0}$ ) where it is converted 615 to thermal energy and electrical energy. The thermal power is either lost ( $\mathrm{q}_{0 a}$ ) to the 616 ambient environment (at temperature $\mathrm{T}_{\mathrm{a}}$ ) or transferred through the thermal diode 617 ( $\mathrm{q}_{03}$ ) to heat the water storage tank (at temperature $\mathrm{T}_{3}$ ) where it becomes available 618 for delivery to thermal loads $\left(\mathrm{q}_{\mathrm{T}}\right)$. Heat transferred from the absorber to the stored 619 water passes through the diode $\left(R_{12}\right)$ and storage tank mantle $\left(R_{23}\right)$ thermal 620 resistances. Some of the solar heat gained by the tank is lost through the insulated 621 tank sidewalls and back plate ( $q_{3 a}$ through $R_{3 i}+R_{i a}$ ). Heat losses through the insulated 622 thermal diode sidewalls $\left(\mathrm{q}_{4 a}\right)$ are neglected as these are small by comparison. Absorber 623 heat losses $\left(q_{1 a}\right)$ pass through the absorber laminate $\left(R_{15}\right)$, transparent cover $\left(R_{6}\right)$, 624 airgap $\left(R_{56}\right)$ and ambient $\left(R_{6 a}\right)$ thermal resistances which act in series to determine the 625 overall absorber loss resistance $\left(R_{1 a}\right)$. It is assumed that each element is isothermal 626 and that heat fluxes are constant across the plane of each element. The amount of 627 electrical power produced by the $P V$ cell array $\left(q_{E}=I_{P V} \cdot V_{P}\right)$ is dependent upon the 628 irradiance $(G)$; the pump and load electrical resistances $\left(R_{P}+R_{l o a d}\right)$; and the $P V$ cell 629 array electrical characteristics (represented by $R_{P V}$ ) which are themselves dependent 630 upon the cell material properties and temperature. Some of the electrical power 631 generated by the PV is delivered to a small pump $\left(q_{p}\right)$ which distributes a working fluid 632 film to wet the PLVTD evaporator and the remainder $\left(q_{E}\right)$ is available to serve applied 633 electrical loads $\left(R_{\text {load }}\right)$. It is assumed that all electrical energy used to drive the pump 634 is eventually converted to heat which is added to the stored water $\left(q_{P, T}=q_{P, E}=I_{P} . V_{P}\right)$.

635 Collection behaviour of the BIPV-PLVTD-ICSSHW can be modelled by considering the 636 energy balances within the absorber laminate (Equation 22), storage tank (Equation 637 23), and connected electrical load (Equation 24) by accounting for the transparent 638 cover transmissivity $(\tau)$; the absorber surface area $\left(A_{1}\right)$ and absorptivity $(\alpha)$; and the 639 electrical currents flowing from the PV output (at voltage $V_{P}$ ) to ground through the 640 PV, pump and load ( $I_{P V}, I_{P}$ and $I_{\text {load }}$ respectively). It should be noted that the optical 641 efficiency $(\tau \alpha)$ is dependent upon the solar incidence angle. Substituting Equation 24 642 into Equation 1, and the resultant expression into Equation 23, yields Equation 25 643 which describes overall thermal power output. In cases where the pump is fed from an 644 external power supply (as occurred for solar simulator laboratory tests described in 645 Part 2 of 2 ) the overall thermal power output is described by Equation 26. 


$$
\tau \cdot \alpha \cdot G \cdot A_{1}=q_{E}+q_{P}+q_{03}+q_{0 a}
$$

$$
q_{T}=q_{03}+q_{P}-q_{3 a}
$$

$$
q_{E}=q_{P V}-q_{P}=V_{P}\left(I_{P V}-I_{P}\right)=V_{P} I_{l o a d}
$$

$$
q_{T}=\tau \cdot \alpha \cdot G \cdot A_{1}-V_{P} I_{l o a d}-q_{0 a}-q_{3 a}
$$

$$
q_{T}=\tau \cdot \alpha \cdot G \cdot A_{1}-V_{P}\left(I_{P V}+I_{P}\right)-q_{0 a}-q_{3 a}
$$

Equation 26

651 Inspection of the thermal resistance network in Figure 6 indicates that absorber heat 652 loss $\left(q_{0 a}\right)$ can be expressed in terms of normalised absorber temperature $\left(\Delta T_{0 a}=T_{0}-T_{a}\right)$ 653 and the series thermal resistances $R_{05}+R_{56}+R_{6}+R_{6 a}$ to create Equation 27 . Tank heat 654 loss $\left(q_{3 a}\right)$ and tank heat gain $\left(q_{03}\right)$ can likewise be expressed in terms of normalised 655 tank temperature $\left(\Delta \mathrm{T}_{3 \mathrm{a}}=\mathrm{T}_{3}-\mathrm{T}_{\mathrm{a}}\right)$ and the absorber-to-tank temperature difference $656\left(\Delta \mathrm{T}_{03}=\mathrm{T}_{0}-\mathrm{T}_{3}\right)$ together with relevant thermal resistances to create Equations $28 \& 29$.

$$
q_{0 a}=\frac{T_{0}-T_{a}}{R_{05}+R_{56}+R_{6}+R_{6 a}}=\frac{\Delta T_{0 a}}{R_{0 a}}
$$

$$
\begin{aligned}
& q_{3 i}=\frac{T_{3}-T_{a}}{R_{3 i}+R_{i a}}=\frac{\Delta T_{3 a}}{R_{3 a}} \\
& q_{03}=\frac{T_{0}-T_{3}}{R_{01}+R_{12}+R_{23}}=\frac{\Delta T_{03}}{R_{03}}
\end{aligned}
$$$$
\text { Equation } 28
$$

660 During collection, absorbed solar radiation is converted to heat and electricity in accordance with the absorber laminate energy balance. Substituting Equations 27 \& 28 into Equation 25; and substituting Equations 28 \& 29 into Equation 23; yields 663 Equations $30 \& 31$ which describe the maximum amount of thermal power that the 664 tank can deliver over a sustained period. Substituting Equations 27 \& 29 into 665 Equation 22 and rearranging into Equation 32 allows the absorber temperature $\left(T_{0}\right)$ to 666 be evaluated. Substituting Equation 30 into Equation 9 allows the solar thermal 667 collection efficiency to be evaluated according to Equation 33. It should be noted that 668 the term $V_{P} I_{P}$ is only relevant when pumping power for the PLVTD evaporator wetter is 669 supplied by the PV cells.

$$
q_{T}=\tau \cdot \alpha \cdot G \cdot A_{1}-V_{P} I_{\text {load }}-\frac{T_{0}-T_{a}}{R_{0 a}}-\frac{T_{3}-T_{a}}{R_{3 a}}
$$

$$
q_{T}=\frac{T_{0}-T_{3}}{R_{03}}+V_{P} I_{P}-\frac{T_{3}-T_{a}}{R_{3 a}}
$$

$$
T_{0}=\frac{\left(R_{03} R_{0 a}\right)\left(\tau \cdot \alpha \cdot G \cdot A_{1}-q_{E}-q_{P}\right)+T_{a} R_{03}+T_{3} R_{0 a}}{R_{03}+R_{0 a}}
$$

$$
\eta_{T}=\frac{\left(T_{0}-T_{3}\right) / R_{03}-\left(T_{3}-T_{a}\right) / R_{3 a}+\left(V_{P} I_{P}\right)}{G \cdot A_{1}}
$$




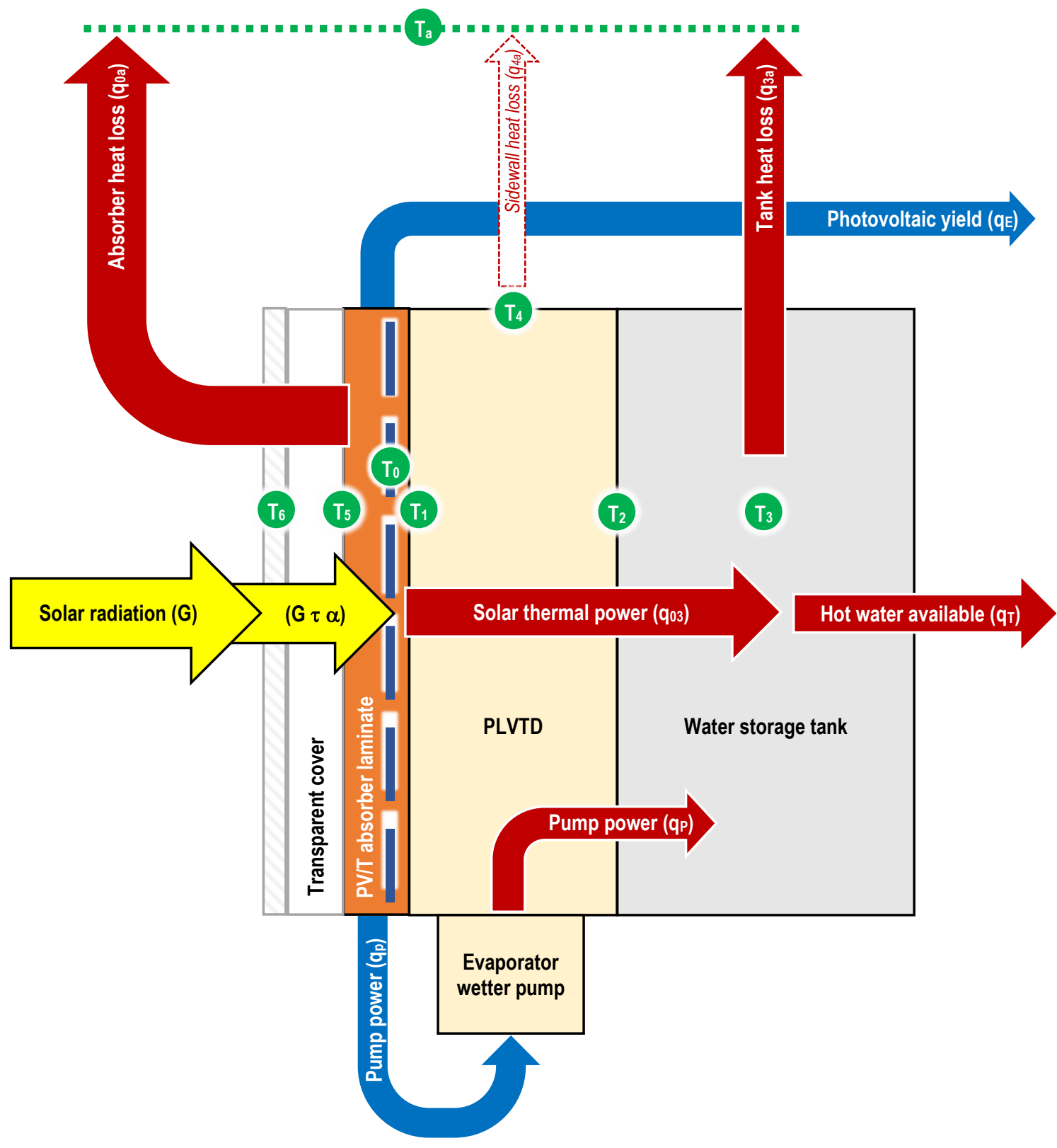

675

\section{$\mathrm{T}_{\mathrm{a}} \quad$ Ambient environmental temperature}

To Photovoltaic cell temperature

$\mathrm{T}_{1} \quad$ Temp. of absorber laminate substrate and evaporator

$\mathrm{T}_{2} \quad$ Temperature of condenser plate and tank mantle

$\mathrm{T}_{3} \quad$ Temperature of water bulk stored in the tank

$\mathrm{T}_{4} \quad$ Thermal diode sidewall temperature

$\mathrm{T}_{5}$ Absorber laminate surface temperature

$\mathrm{T}_{6} \quad$ Transparent cover temperature
G Incident solar radiation flux

G $\tau$ A Absorbed solar radiation

q03 Thermal power transferred from the absorber to the water storage tank through the thermal diode

qT Net rate of heat gained by the stored water bulk

q0a Absorber heat loss rate

Rate of heat loss from the back and sides of the water storage tank not covered by the thermal diode

qE Net electrical power yielded

qp Electrical power consumed by the evaporator wetter pump which is then all converted to heat 


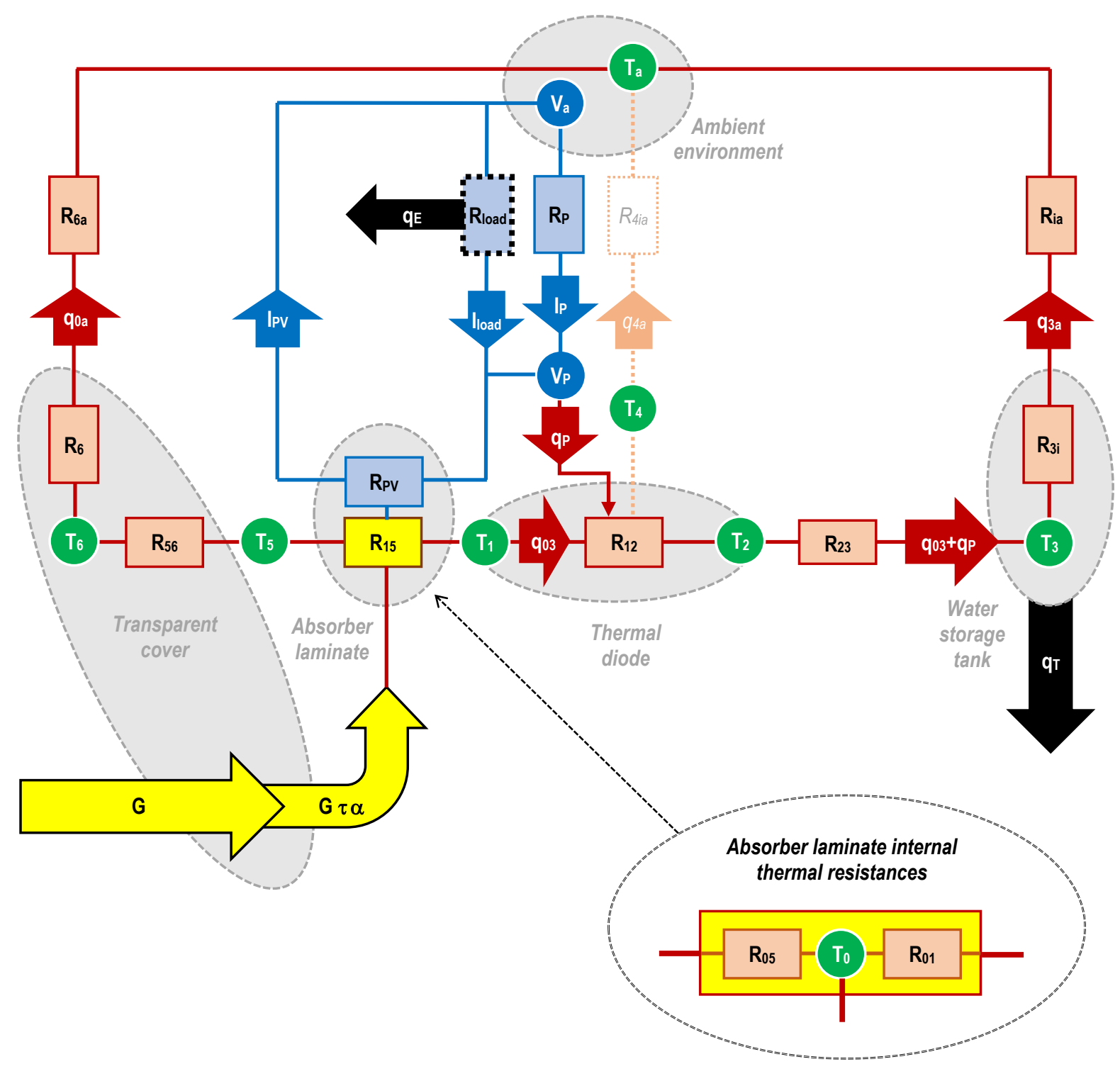

\begin{tabular}{|l|l|l|l|}
\hline$G \tau \alpha$ & Absorbed solar radiation & $V_{P}$ & Evaporator wetter pump supply voltage \\
\hline$q_{T+E}$ & Thermal and electrical power available for use & $V_{a}$ & Earth electrical potential (zero voltage) \\
\hline$q_{0 a}$ & Heat lost from the absorber & $I_{P V}$ & Current delivered by the photovoltaic module \\
\hline$q_{03}$ & Solar thermal power transferred to tank & $I_{\text {load }}$ & Current drawn by the load \\
\hline$q_{3 a}$ & Heat lost from the water storage tank & $I_{P}$ & Current drawn by the evaporator wetter pump \\
\hline$q_{P}$ & Wetter pump power (electrical becomes thermal) & $R_{\text {load }}$ & Electrical load connected to photovoltaic module \\
\hline$R_{1 a}$ & Overall absorber heat loss thermal resistance & $R_{P V}$ & Electrical resistance of photovoltaic module \\
\hline$R_{23}$ & Water storage tank mantle thermal resistance & $R_{P}$ & Electrical load of the evaporator wetter pump \\
\hline$R_{3 i}+R_{i a}$ & Water storage tank back and side insulation & $T_{a}$ & Ambient environmental temperature \\
\hline$R_{4 i a}$ & Thermal diode sidewall insulation (assumed infinite) & $T_{0}$ & Photovoltaic cell temperature \\
\hline$R_{56}$ & Air gap between absorber and transparent cover & $T_{1}$ & Absorber substrate \& evaporator plate temperature \\
\hline$R_{6}$ & Transparent cover thermal resistance & $T_{2}$ & Temperature of condenser plate and tank mantle \\
\hline$R_{6 a}$ & External air convection \& radiation to ambient & $T_{3}$ & Temperature of water bulk stored in the tank \\
\hline$R_{15}$ & Absorber laminate thermal resistance & $T_{4}$ & Thermal diode sidewall temperature \\
\hline$R_{01}$ & Thermal resistance of laminate behind cells & $T_{5}$ & Absorber laminate surface temperature \\
\hline$R_{05}$ & Thermal resistance of laminate in front of cells & $T_{6}$ & Transparent cover temperature \\
\hline
\end{tabular}




$$
U_{r, s y s}=\frac{1}{A_{s y s}}\left[\frac{1}{R_{3 a}}+\frac{1}{\left(R_{03}+R_{0 a}\right)}\right]
$$

$$
\eta_{T, r e t}=\frac{M \cdot c_{p} \Delta T_{3 a\left[t=t_{c o l}\right]}-t_{r e t}\left[\left(\tilde{T}_{3\left[t_{r e t}\right]}-\tilde{T}_{0\left[t_{r e t}\right]}\right) / R_{03}-\left(\tilde{T}_{3\left[t_{r e t}\right]}-\tilde{T}_{a\left[t_{r e t}\right]}\right) / R_{3 i a}\right]}{M c_{p}\left(T_{3\left[t=t_{c o l}\right]}-T_{a\left[t=t_{c o l}\right]}\right)} \quad \text { Equation } 35
$$

$$
F=\frac{\mathrm{R}_{0 \mathrm{a}}}{\mathrm{R}_{03}+\mathrm{R}_{0 \mathrm{a}}}\left[\frac{G \cdot A_{1}-q_{E}}{G \cdot A_{1}}\right]
$$

$$
F \cdot U_{L}=\frac{1}{A_{1}}\left[\frac{1}{R_{3 a}}+\frac{1}{\left(R_{03}+R_{0 a}\right)}\right]\left[\frac{G \cdot A_{1}-q_{E}}{G \cdot A_{1}}\right]
$$

Equation 37

685 At night when there is no solar radiation $\left(G=q_{E}=q_{P}=0\right)$ the network on Figure 6 686 simplifies somewhat because the electrical elements become inactive and there is no 687 solar flux component. The tank loses heat to the absorber at the same rate as the 688 absorber loses heat to the ambient such that Equation 22 simplifies to $\mathrm{q}_{03}+\mathrm{q}_{0 a}=0$ and 689 the electrical and optical terms of Equations 30-32 become zero. The heat loss 690 coefficient can be expressed in terms of thermal resistances according to Equation 34. 691 Likewise, combining Equations 14 \& 31 yields Equation 35 which enables the heat 692 retention efficiency to be evaluated. Heat removal factor can be evaluated using 693 Equation 36 (obtained from inspection of Figure 6) or Equation 37 (obtained by 694 substituting Equation 34 into Equation 10). It is interesting to note that in the case of 695 a thermal-only collector $\left(q_{E}=0\right)$, inspection of Equation 36 confirms that $F \rightarrow 1$ when $696 \mathrm{R}_{0 \mathrm{a}} \rightarrow \infty$ or $\mathrm{R}_{03} \rightarrow 0$; $\mathrm{F} \rightarrow 0$ when $\mathrm{R}_{03} \rightarrow \infty$ or $\mathrm{R}_{0 \mathrm{a}} \rightarrow 0$; and $\mathrm{F}=0.5$ when $\mathrm{R}_{03}=\mathrm{R}_{0 \mathrm{a}}$.

\section{Thermal diodicity and its effect on performance}

698 Diodicity coefficient $(s)$ is a dimensionless measure of thermal rectification and is a useful performance measure for thermal diodes. It is commonly defined according to Equation 38 as a scalar based on the apparent thermal conductivities $(k)$ of the device in forward ( $f$ ) heat transfer mode and reverse ( $r$ ) insulation modes. It can alternatively

702 be written in terms of thermal power $(q)$, heat flux (q/A), thermal conductance $703(\mathrm{U}=\mathrm{k} / \mathrm{x})$, or reciprocal thermal resistance $(1 / \mathrm{R}=\mathrm{UA})$. A reasonable target for diodicity of PLVTDs in ICSSWH applications would be $\varsigma>99 \%$ to replicate absorber transparent cover arrangements in ICSSWH devices where the insulation of high quality double glazing unit is $\mathrm{U} \approx 1.2 \mathrm{~W} \cdot \mathrm{m}^{-2} \mathrm{~K}^{-1}$ (Twidell \& Weir, 2006) and heat transfer across the absorber should be U>200W· $\mathrm{m}^{-2} \mathrm{~K}^{-1}$ (Dupeyrat et al., 2011, Deng et al., 2019).

$$
\varsigma=\frac{k_{f}-k_{r}}{k_{f}+k_{r}} \quad(0 \geq \varsigma \geq 1)
$$
represented in the lumped parameter model by thermal resistance $\left(R_{12}=1 / U_{12} A_{1}\right)$. 
711 Inspection of Figure 6 highlights that this is a key component in the absorber-to-store 712 thermal resistance $R_{03}=R_{01}+R_{12}+R_{23}$ which has a major influence upon the absorber 713 temperature $\left(T_{0}\right)$, heat removal factor $(F)$ and heat loss coefficients $\left(U_{L}\right.$ and $\left.U_{\text {sys }}\right)$ as 714 described by Equations 29-37. Given that the solar thermal and photovoltaic collection 715 efficiencies are dependent upon $\mathrm{F} \cdot \mathrm{U}_{\mathrm{L}}$ and $\mathrm{T}_{0}$ respectively, and that the heat retention 716 behaviour is determined by $U_{r, s y s}$, it is very clear that the $U_{12}$ of the PLVTD has a major 717 influence upon performance. To quantify this, the model described in the preceding 718 sections has been used to examine how thermal diode resistances affect the 719 performance of a notional BIPV-PLVTD-ICSSWH with $A_{1}=1 \mathrm{~m}^{2}$ collection area, $u=100 \mathrm{~L}$ 720 storage tank, and the component properties set out in Table 3.

721 Pugsley et al. (2019 \& 2020) proposed and validated calculation methods and a 722 parametric design approach for evaluating the thermal resistances exhibited by a 723 PLVTD and developed a working prototype. Tests demonstrated that the prototype $724\left(A=0.98 \mathrm{~m}^{2}\right.$ and $\mathrm{x}=70 \mathrm{~mm}$ deep $)$ achieved reverse mode insulation of $725 \mathrm{U}_{\mathrm{r}, 12}=1.7 \mathrm{~W} \cdot \mathrm{m}^{-2} \mathrm{~K}^{-1}$ (equivalent to $\mathrm{R}_{12}=0.6 \mathrm{~K} / \mathrm{W}$ ) and typical forward mode heat transfer 726 of $U_{f, 12}=38 \mathrm{~W} \cdot \mathrm{m}^{-2} \mathrm{~K}^{-1}$ (equivalent to $\mathrm{R}_{12}=0.03 \mathrm{~K} / \mathrm{W}$ ) corresponding to diodicity of $727 \varsigma \approx 90 \%$. Analysis concluded that an order of magnitude increase in forward mode 728 performance could feasibly be realised by improving evaporator wetting uniformity.

729 Equations 5-10, $32 \& 37$ have been used to calculate the results on Figures $7 \& 8$ which 730 illustrate how varying forward mode thermal conductance $\left(1<\mathrm{U}_{\mathrm{f}, 12}<1000 \mathrm{~W} \cdot \mathrm{m}^{-2} \mathrm{~K}^{-1}\right.$, 731 equivalent to $\left.0.001<R_{12}<1 \mathrm{~K} / \mathrm{W}\right)$ affects the solar thermal collection efficiency $\left(\eta_{\mathrm{T}, \mathrm{col}}\right)$ 732 and $\mathrm{PV} / \mathrm{T}$ performance ratio $\left(\mathrm{PR}_{\mathrm{T} 3}\right)$. Low diode thermal conductance impairs absorber733 to-tank heat transfer causing high absorber temperatures which increase heat losses 734 (thus poor solar thermal collection efficiencies on Figure 7) and resistive electrical 735 losses (thus poor PV/T performance ratios on Figure 8). The degree to which low diode 736 thermal conductance adversely affects performance is dependent upon operating 737 conditions ( $G, T_{a}, T_{3}$, wind speed and electrical loads) but follows a similar trend for all 738 scenarios investigated. A notional "knee" point is apparent at $\mathrm{U}_{\mathrm{f}, 12} \approx 100 \mathrm{~W} \cdot \mathrm{m}^{-2} \mathrm{~K}^{-1}$, 739 above which minimal performance benefit is gained for order of magnitude increases. 740 This knee corresponds closely to the point at which the zero-loss solar thermal 741 collection efficiencies of bare and covered collectors are approximately equal $742\left(\eta_{T, c o l} \approx 75 \%\right.$ at $\mathrm{N} \approx 0 \mathrm{~m}^{2} \mathrm{~K} \cdot \mathrm{W}^{-1}$, no wind, no load $)$.

743 The target benchmark solar thermal collection efficiency $\left(\eta_{T, c o l} \approx 60 \%\right.$ at $744 \mathrm{~N} \approx 0.035 \mathrm{~m}^{2} \mathrm{~K} \cdot \mathrm{W}^{-1}$ and $2 \mathrm{~m} / \mathrm{s}$ wind speed, established in Table 2) is narrowly missed $745\left(\eta_{T, c o l} \approx 58 \%\right)$ for a covered BIPV-PLVTD-ICSSWH with $\mathrm{U}_{\mathrm{f}, 12} \approx 100 \mathrm{~W} \cdot \mathrm{m}^{-2} \mathrm{~K}^{-1}$ but is 
746 achievable under "no wind" conditions or if the diode thermal conductance is increased

747 to $\mathrm{U}_{\mathrm{f}, 12} \approx 500 \mathrm{~W} \cdot \mathrm{m}^{-2} \mathrm{~K}^{-1}$. Whilst Figure 7 clearly shows that a transparent cover and air 748 gap is essential for achieving the solar thermal performance benchmark (this is 749 unachievable for a bare absorber, irrespective of $U_{f, 12}$ or wind speed), the PR curves 750 on Figure 8 illustrate how the corresponding reduction in transmissivity reduces the 751 photovoltaic performance. PV/T performance ratios are worst when diode thermal 752 conductance is low, ambient temperature is high, and the collector is operating close 753 to the zero-loss solar thermal condition $(\mathrm{N}=0)$. The maximum achievable PR value is 754 limited by the PV cell packing factor which in the modelled case is $A_{0} / A_{1}=75 \%$ but with 755 careful design could feasibly be $A_{0} / A_{1} \approx 90 \%$ to enable the benchmarks discussed in 756 Section 2.2 to be achieved.

757 Equations 15, 34 \& 37 have been used to calculate the results shown in Figure 9 which 758 illustrate how varying the reverse mode thermal conductance $759\left(0.1<\mathrm{U}_{\mathrm{r}, 12}<100 \mathrm{~W} \cdot \mathrm{m}^{-2} \mathrm{~K}^{-1}\right.$, equivalent to $\left.0.01<\mathrm{R}_{12}<10 \mathrm{~K} / \mathrm{W}\right)$ affects the overall heat 760 loss coefficient $\left(U_{r, s y s} A_{s y s} / u\right)$ and the corresponding overnight heat retention efficiency $761\left(\eta_{T, \text { ret }}\right.$ for $a t_{r e t}=12 \mathrm{~h}$ period $)$. It is clear that overnight heat loss increases with increasing 762 diode thermal conductance. High $U_{r, 12}$ values worsen vulnerability to wind induced heat 763 losses, especially when the bare absorber is exposed (no cover). On the basis of the $764 \mathrm{U}_{\mathrm{r}, 12}=1.7 \mathrm{~W} \cdot \mathrm{m}^{-2} \mathrm{~K}^{-1}$ reported by Pugsley et al. (2020), the results suggest that the BIPV765 PLVTD-ICSSWH design described by Figure 1 and Table 3 would achieve $\eta_{\text {T,ret }}>80 \%$ 766 and a heat loss coefficient of $U_{r, s y s} A_{s y s} / u \approx 20 \mathrm{~W} \cdot \mathrm{m}^{-3} \mathrm{~K}^{-1}$ which is better than most of the 767 ICSSWHs encountered in the literature (see Table 2) but somewhat shy of $768 \mathrm{U}_{\mathrm{r}, \mathrm{sys}} \mathrm{A}_{\mathrm{sys}} / \mathrm{u}<10 \mathrm{~W} \cdot \mathrm{m}^{-3} \mathrm{~K}^{-1}$ benchmark target. Achieving the benchmark would require the 769 reverse mode PLVTD thermal conductance to be $U_{r, 12}<0.5 \mathrm{~W} \cdot \mathrm{m}^{-2} \mathrm{~K}^{-1}$. Further 770 interrogation of the model suggests that diode performance is relatively less important 771 if absorber heat loss is better controlled (double glazing and/or low emissivity surface 772 treatments) or if the tank is poorly insulated. 
Table 3: Basis and assumptions for the modelled BIPV-PLVTD-ICSSWH

\begin{tabular}{|c|c|c|c|}
\hline Quantity & Value & Unit & Basis \\
\hline Volume of water in storage tank $(\mathrm{u})$ & 0.1 & $\mathrm{~m}^{3}$ & Typical tank size reported in literature \\
\hline Aperture and absorber area $\left(A_{1}\right)$ & 1 & $m^{2}$ & Typical absorber size reported in literature \\
\hline PV cell coverage of absorber area $\left(A_{0}\right)$ & 0.75 & $m^{2}$ & 15 strings, each formed of 8 quarter-cell pieces $(78 \times 78 \mathrm{~mm})$ \\
\hline Depth of PLVTD $\left(x_{12}\right)$ & 70 & $\mathrm{~mm}$ & Dimension as discussed by Pugsley et al. (2020) \\
\hline Depth of tank $\left(\mathrm{x}_{3}\right)$ & 100 & $\mathrm{~mm}$ & Tank volume divided by absorber area \\
\hline $\begin{array}{l}\text { Absorber-to-ambient conductance }\left(\mathrm{U}_{5 \mathrm{a}} \text {, bare }\right) \\
5 \mathrm{~mm} \text { clear acrylic bonded to } \mathrm{PV} \text { cells, no air gap }\end{array}$ & $10.9^{*}$ & $W \cdot m^{-2} K^{-1}$ & $\begin{array}{l}\text { Calculated from radiative \& convective components as per Twidell \& } \\
\text { Weir (2006) assumes } T_{5}=50^{\circ} \mathrm{C}, \mathrm{T}_{a}=15^{\circ} \mathrm{C}, \varepsilon_{5}=0.8, \varepsilon_{6}=0.9\end{array}$ \\
\hline $\begin{array}{l}\text { Absorber-to-ambient conductance }\left(U_{5 a} \text {, covered }\right) \\
\text { as above }+30 \mathrm{~mm} \text { air }+3 \mathrm{~mm} \text { clear acrylic cover }\end{array}$ & $4.0^{*}$ & $W \cdot m^{-2} K^{-1}$ & $\begin{array}{l}\text { Calculated from radiative \& convective components as per Twidell \& } \\
\text { Weir (2006) assumes } T_{5}=50^{\circ} \mathrm{C}, T_{a}=15^{\circ} \mathrm{C}, \varepsilon_{5}=0.8\end{array}$ \\
\hline PV cell-to-absorber thermal conductance $\left(\mathrm{U}_{01}\right)$ & 400 & $W \cdot m^{-2} K^{-1}$ & Polymer bonding layer $0.5 \mathrm{~mm}$, thermal conductivity $\mathrm{k}=0.2 \mathrm{~W} \cdot \mathrm{m}^{-1} \mathrm{~K}^{-1}$ \\
\hline PV cell-to-air thermal conductance $\left(\mathrm{U}_{05}\right)$ & 40 & $W \cdot m^{-2} K^{-1}$ & Bonded transparent cover $5 \mathrm{~mm}$, thermal conductivity $\mathrm{k}=0.2 \mathrm{~W} \cdot \mathrm{m}^{-1} \mathrm{~K}^{-1}$ \\
\hline Tank wall-to-water thermal conductance $\left(\mathrm{U}_{23}\right)$ & 250 & $\mathrm{~W} \cdot \mathrm{m}^{-2} \mathrm{~K}^{-1}$ & $\begin{array}{l}\text { Natural convection heating of fluid adjacent to a vertical plate for } \\
\mathrm{T}_{2}=50^{\circ} \mathrm{C}, \mathrm{T}_{3}=49^{\circ} \mathrm{C} \text { equations recommended by Pugsley et al. (2020) }\end{array}$ \\
\hline Tank insulation thermal conductance $\left(\mathrm{U}_{3 \mathrm{a}}\right)$ & 0.25 & $W \cdot m^{-2} K^{-1}$ & Rigid foam insulation $100 \mathrm{~mm}$, thermal conductivity $\mathrm{k}=0.025 \mathrm{~W} \cdot \mathrm{m}^{-1} \mathrm{~K}^{-1}$ \\
\hline $\begin{array}{l}\text { Optical transmissivity ( } \tau \text {, bare) } \\
5 \mathrm{~mm} \text { clear acrylic bonded to PV cells, no air gap }\end{array}$ & 96 & $\%$ & $\begin{array}{l}\text { Estimated from optical reflection and absorption loss analysis offered by } \\
\text { Kalogirou (2009) assuming normal incidence. }\end{array}$ \\
\hline $\begin{array}{l}\text { Optical transmissivity ( } \tau \text {, covered) } \\
\text { as above }+30 \mathrm{~mm} \text { air }+3 \mathrm{~mm} \text { clear acrylic cover }\end{array}$ & 88 & $\%$ & $\begin{array}{l}\text { Estimated from optical reflection and absorption loss analysis offered by } \\
\text { Kalogirou (2009) assuming normal incidence. }\end{array}$ \\
\hline Optical absorptivity of PV cells $(\alpha)$ & 90 & $\%$ & Value suggested by Dupeyrat et al. (2011) for mc-si PV cells \\
\hline Optical emissivity of encapsulated PV cells $(\varepsilon)$ & 80 & $\%$ & Nominal value for PV with bonded polymer cover, from Zondag (2008) \\
\hline Standard power output of PV cell (qsTc) & 4.24 & W & 156x156mm pseudo square mc-si M-2BB solar PV cell (Bosch, 2010) \\
\hline Voltage-temperature coefficient $\left(\mathrm{K}_{\mathrm{V}: \mathrm{T}}\right)$ & -0.37 & $\% / K$ & 156x156mm pseudo square mc-si M-2BB solar PV cell (Bosch, 2010) \\
\hline Current-temperature coefficient $\left(\mathrm{K}_{\mathrm{l}: \mathrm{T}}\right)$ & +0.03 & $\% / \mathrm{K}$ & 156x156mm pseudo square mc-si M-2BB solar PV cell (Bosch, 2010) \\
\hline
\end{tabular}

Values were chosen to be representative of the BIPV-PLVTD-ICSSWH prototype used for the experimental work (see Part 2 of 2). Stated values of $\mathrm{U}_{5 \mathrm{a}}$ marked with asterisk* relate to the "no wind" condition. Model accounts for effect of $\mathrm{U}_{5 \mathrm{a}}$ increasing with increasing local wind speed according to the relation offered by Twidell \& Weir (2006). Calculations assume that evaporator wetter pump power is negligible $\left(q_{p} \approx 0\right)$ and that the external electrical load has a resistance which enables operation at maximum power point. 


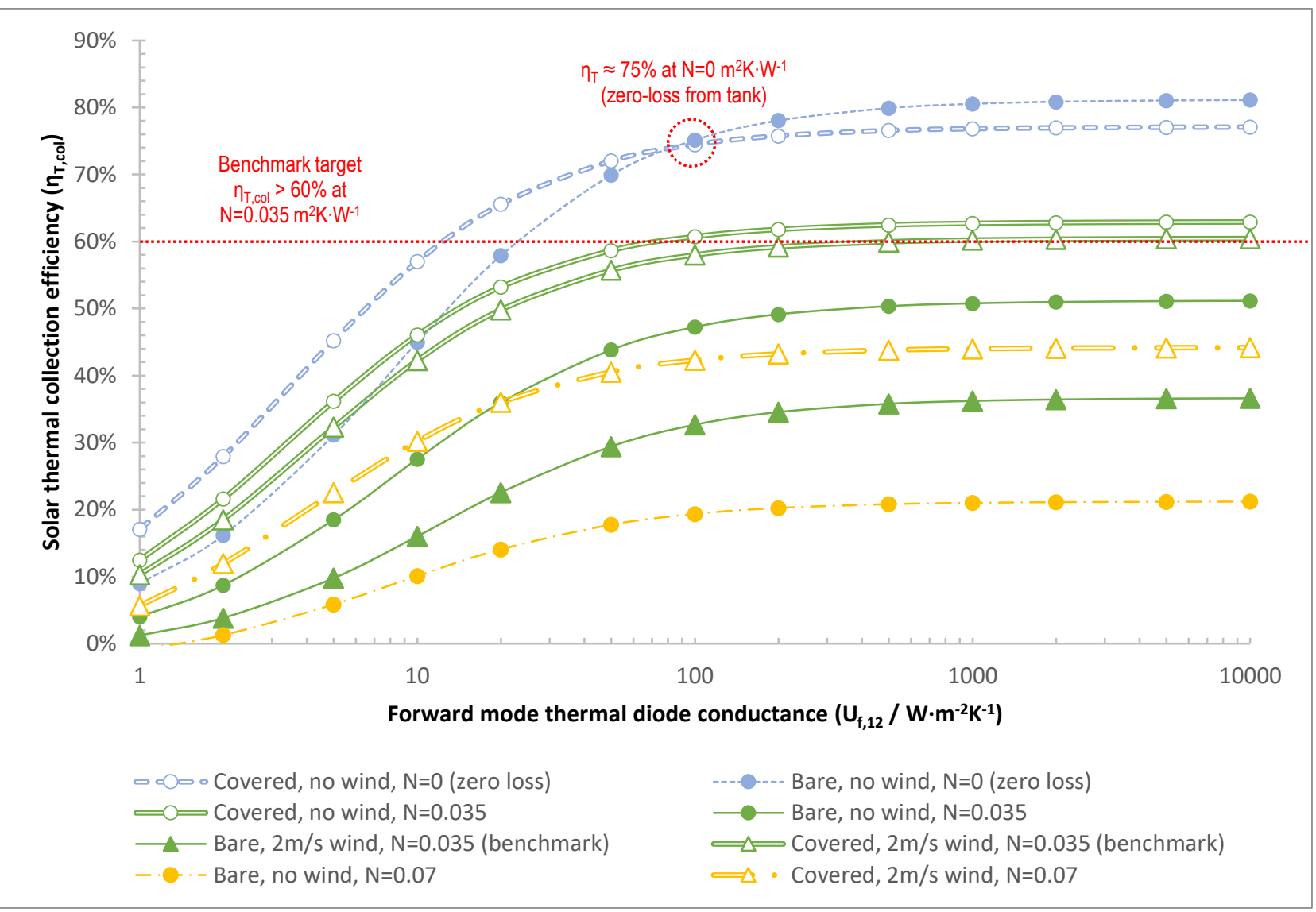

Figure 7: Dependence of solar thermal collection efficiency upon forward mode thermal diode conductance (zero electrical load $q_{\mathrm{E}}=0$ )

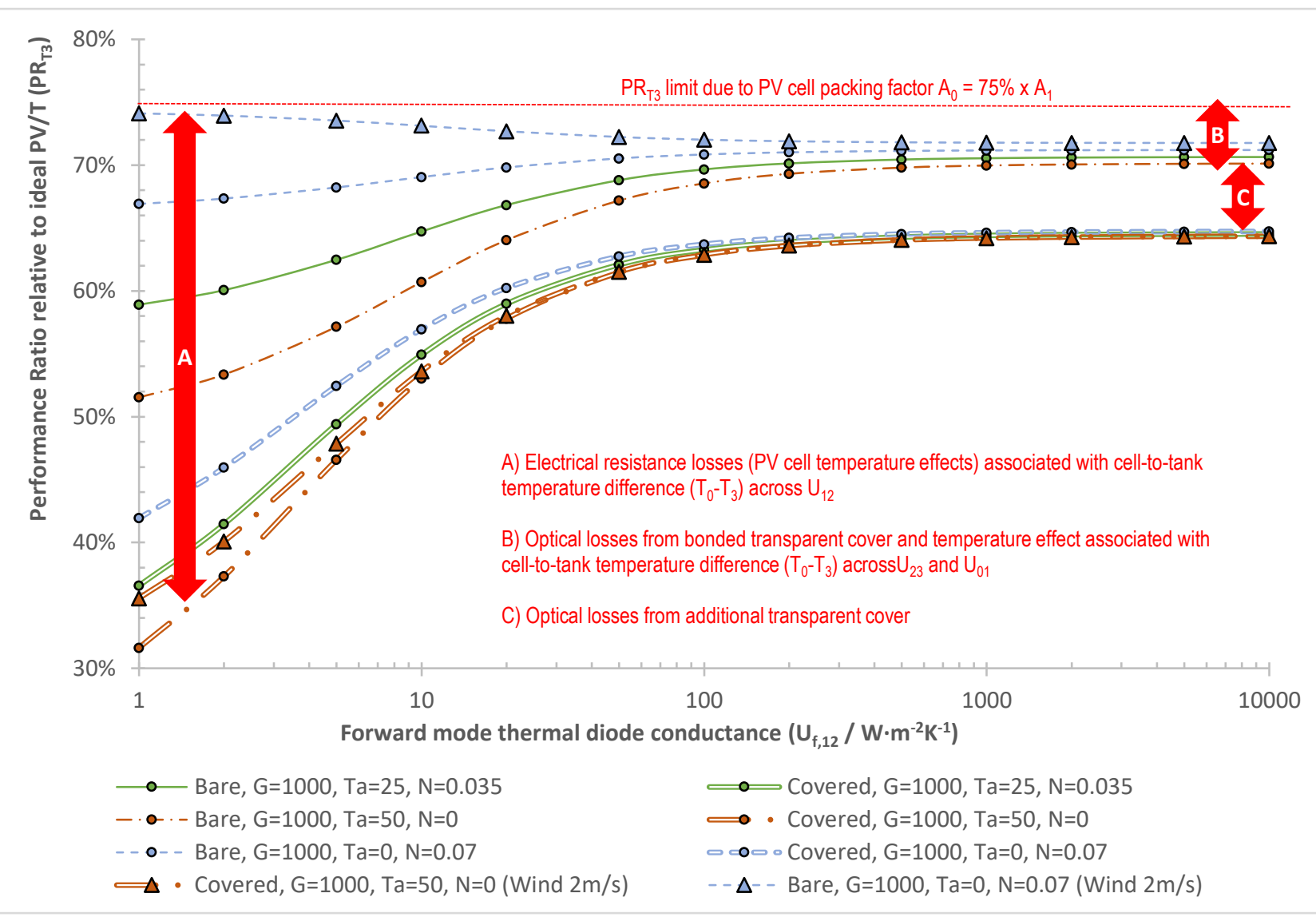




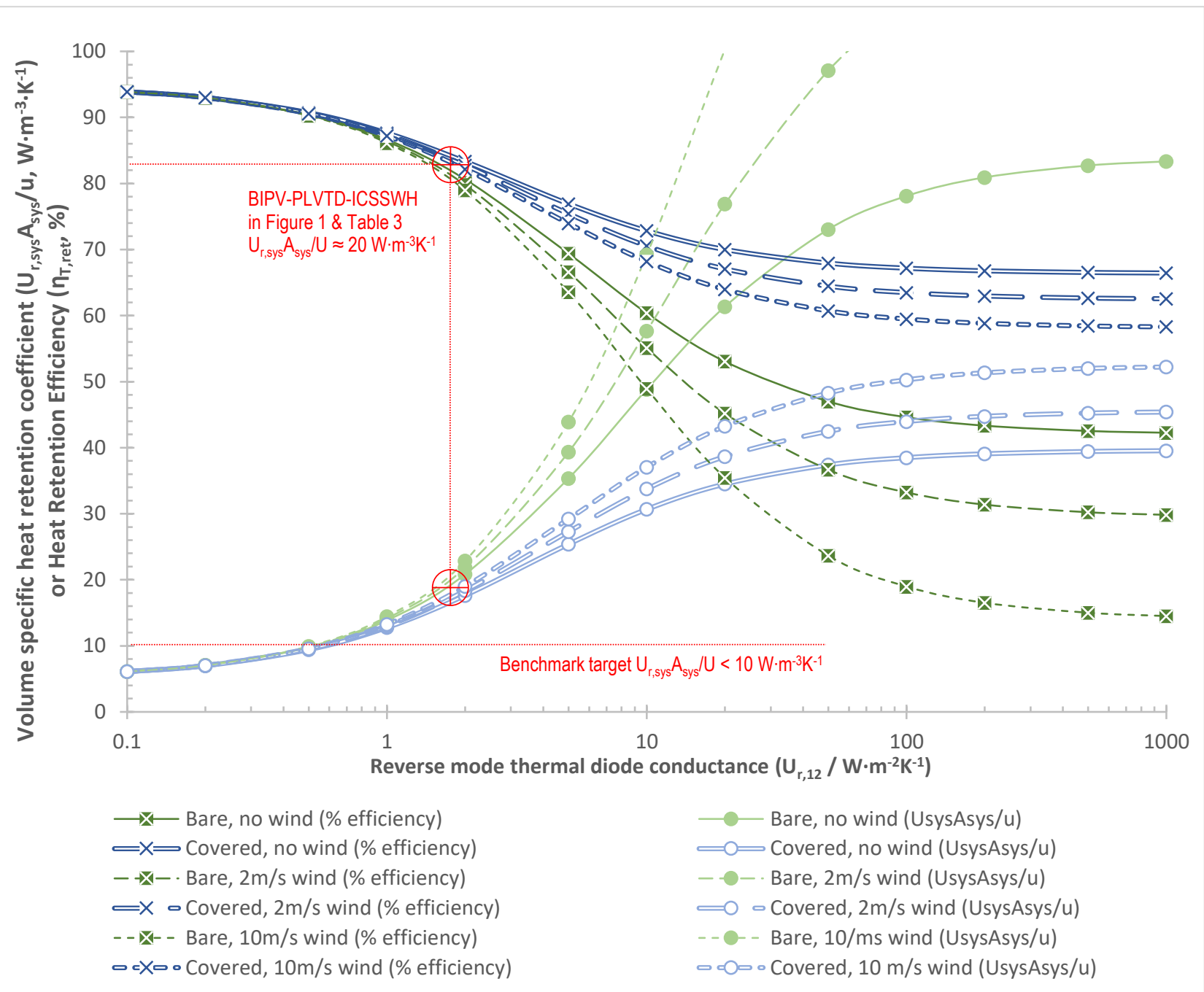

Figure 9: Dependence of overnight heat retention performance upon reverse mode thermal diode conductance

\section{$787 \quad 3.3 \quad$ Behaviour in different climates}

788 Figure 11 compares predicted behaviours of different BIPV-PLVTD-ICSSWH devices to 789 illustrate the overall influence of the PLVTD upon water storage tank temperature $\left(T_{3}\right.$, 790 assumed fully mixed), diurnal thermal efficiency $\left(\eta_{T, 24}\right)$ and maximum power point 791 photovoltaic efficiency $\left(\eta_{E, m p}\right)$ over a multi-day period without thermal load (ie no hot 792 water draw-offs). Results were calculated using Equations 5-10, 15-21, 32, 34 \& 37 793 based upon the physical attributes described in Figure 1 and Table 3; a wind speed of $7942 \mathrm{~m} / \mathrm{s}$; data for summertime average daily solar insolation on a vertical equator facing 795 surface in Rome $\left(\mathrm{H}_{24}=12 \mathrm{MJ} / \mathrm{m}^{2}\right.$, see Table 1$)$; and corresponding average ambient 796 temperatures of $\mathrm{T}_{a}=25^{\circ} \mathrm{C}$ during daytime and $\mathrm{T}_{a}=19^{\circ} \mathrm{C}$ at night (NASA, 2019). The 797 three modelled variants are summarised on Figure 10. 
(A) BIPV-ICSSWH collector without thermal diode

Typical thermal diode forward and reverse mode conductances as reported by Pugsley et al. (2016, 2017 and 2020).

Figure 11: Investigated model variants

(C) PV/T collector with near-ideal thermal diode $\varsigma \approx 99.98 \%$ based upon $\mathrm{U}_{\mathrm{f}, 12}=1000 \mathrm{~W} \cdot \mathrm{m}^{-2} \mathrm{~K}^{-1}$ and $\mathrm{U}_{\mathrm{r}, 12}=0.1 \mathrm{~W} \cdot \mathrm{m}^{-2} \mathrm{~K}^{-1}$

This would in principle behave in a similar manner to a fin and tube PV/T (Dupeyrat et al., 2011) with a separate indoor insulated water storage tank connected via a pumped hydraulic loop.

801 Figure 11 shows how tank temperatures (starting at $\mathrm{T}_{3}=\mathrm{T}_{a}=25^{\circ} \mathrm{C}$ ) rise each day (solar

802 collection) and fall each night (net heat losses) during an 8-day period of summertime 803 stagnation (eg no thermal load due to a building being unoccupied during vacations). 804 All three device variants achieve similar zero-loss solar thermal efficiencies $\left(\eta_{T} \approx 75 \%\right.$ 805 at $\mathrm{N}=0 \mathrm{~m}^{2} \mathrm{~K} \cdot \mathrm{W}^{-1}$ as per Figure 7) and therefore also achieve similar maximum tank 806 temperatures $\left(T_{3} \approx T_{a}+13 \approx 38^{\circ} \mathrm{C}\right)$ and average electrical efficiencies $\left(\eta_{E} \approx 11 \%\right)$ during 807 Day 1. However, their differing overnight heat loss coefficients result in differing tank 808 temperatures by dawn the next day, which causes differences in overall Day 1 diurnal 809 thermal efficiencies $\left(\eta_{T, 24}=\eta_{T, \text { col }} \cdot \eta_{T, \text { ret }}\right)$ such that the conventional PV/T with separate 810 tank performs best (Variant C: $\eta_{T, 24}=42 \%$ ), the BIPV-ICSSWH without thermal diode 811 performs worst (Variant $A: \eta_{T, 24}=28 \%$ ) and the BIPV-PLVTD-ICSSWH achieves a good 812 compromise (Variant $\mathrm{B}: \eta_{\mathrm{T}, 24}=35 \%$ ). After 8 days stagnation, tank temperatures have 
813 risen to $\mathrm{T}_{3}=46^{\circ} \mathrm{C}, 55^{\circ} \mathrm{C}$ and $64^{\circ} \mathrm{C}$ for Variants $\mathrm{A}, \mathrm{B}$ and $\mathrm{C}$ respectively. Consequently,

814 in terms of Day 8 performances, the conventional PV/T with separate tank performs

815 worst (Variant $C: \eta_{T, 24}=10.6 \%$ and $\eta_{E} \approx 10.0 \%$ ) and the BIPV-ICSSWH without thermal

816 diode performs best (Variant $A: \eta_{T, 24}=21.4 \%$ and $\eta_{E} \approx 10.8 \%$ ). The device with the

817 BIPV-PLVTD-ICSSWH again achieves a compromise (Variant B: $\eta_{T, 24}=17.1 \%$ and

$\left.818 \eta_{E} \approx 10.3 \%\right)$. Figure 11 results were calculated based on average summer conditions

819 for a south facing wall in Rome. In practice, the ambient temperatures and insolation

820 levels during a particularly hot and sunny period could be considerably higher than

821 average, and those typically occurring during winter would be notably lower.

822 Dupeyrat et al. (2011) suggest that $85^{\circ} \mathrm{C}$ is an appropriate maximum temperature

823 limit for PV/T absorbers constructed using conventional Ethylene Vinyl Acetate (EVA)

824 lamination techniques. Calculations based on $\mathrm{H}_{24}=20 \mathrm{MJ} / \mathrm{m}^{2}, \mathrm{~T}_{\mathrm{a}}=35^{\circ} \mathrm{C}$ during daytime,

825 and $\mathrm{T}_{\mathrm{a}}=25^{\circ} \mathrm{C}$ at night, and no wind, suggest that maximum summertime tank and

826 absorber stagnation temperatures could reach a potentially damaging $\mathrm{T}_{3} \approx \mathrm{T}_{0} \approx 106^{\circ} \mathrm{C}$ in

827 the case of a conventional PV/T (Variant C) but would be maintained at a lower and

828 safer maximum temperature of $\mathrm{T}_{3} \approx \mathrm{T}_{0} \approx 86^{\circ} \mathrm{C}$ in the case of the BIPV-PLVTD-ICSSWH

829 (Variant $B$ ) and would reach only $T_{3} \approx T_{0} \approx 67^{\circ} \mathrm{C}$ in the case of a simple BIPV-ICSSWH

830 without PLVTD (Variant A). This clearly demonstrates the benefit of the BIPV-ICSSWH

831 concept in respect of minimising stagnation temperatures. In practice, conventional

832 PV/T systems require continuous pumping of heat transfer fluid from the collector to

833 the tank during sunny periods, otherwise much higher absorber stagnation

834 temperatures will occur $\left(T_{0}>150^{\circ} \mathrm{C}\right)$. Inherent electricity demands to run pumps would

835 significantly reduce net electrical yields. By contrast, a BIPV-ICSSWH or BIPV-PLVTD-

836 ICSSWH approach does not require pumps to operate when there is no thermal

837 demand, hence the net electrical yield would be higher than for conventional PV/T.

838 Calculations for a typical winter scenario in Rome based on $\mathrm{H}_{24}=12.4 \mathrm{MJ} / \mathrm{m}^{2}$ (see

839 Table 1$), T_{a}=14^{\circ} \mathrm{C}$ during daytime, and $T_{a}=8^{\circ} \mathrm{C}$ at night, and $5 \mathrm{~m} / \mathrm{s}$ wind, suggest that

840 the Day 1 diurnal thermal efficiency of a BIPV-PLVTD-ICSSWH (Variant B: $\eta_{\mathrm{T}, 24=30 \% \text { ) }}$

841 would be notably better than that of a BIPV-ICSSWH without PLVTD (Variant A:

$842 \eta_{T, 24}=21 \%$ ), although slightly worse than for conventional PV/T (Variant C: $\eta_{T, 24}=38 \%$ ).

843 This clearly demonstrates the benefit of incorporating a PLVTD to reduce overnight

844 heat losses and thus make heat available during the night and early morning hours. 


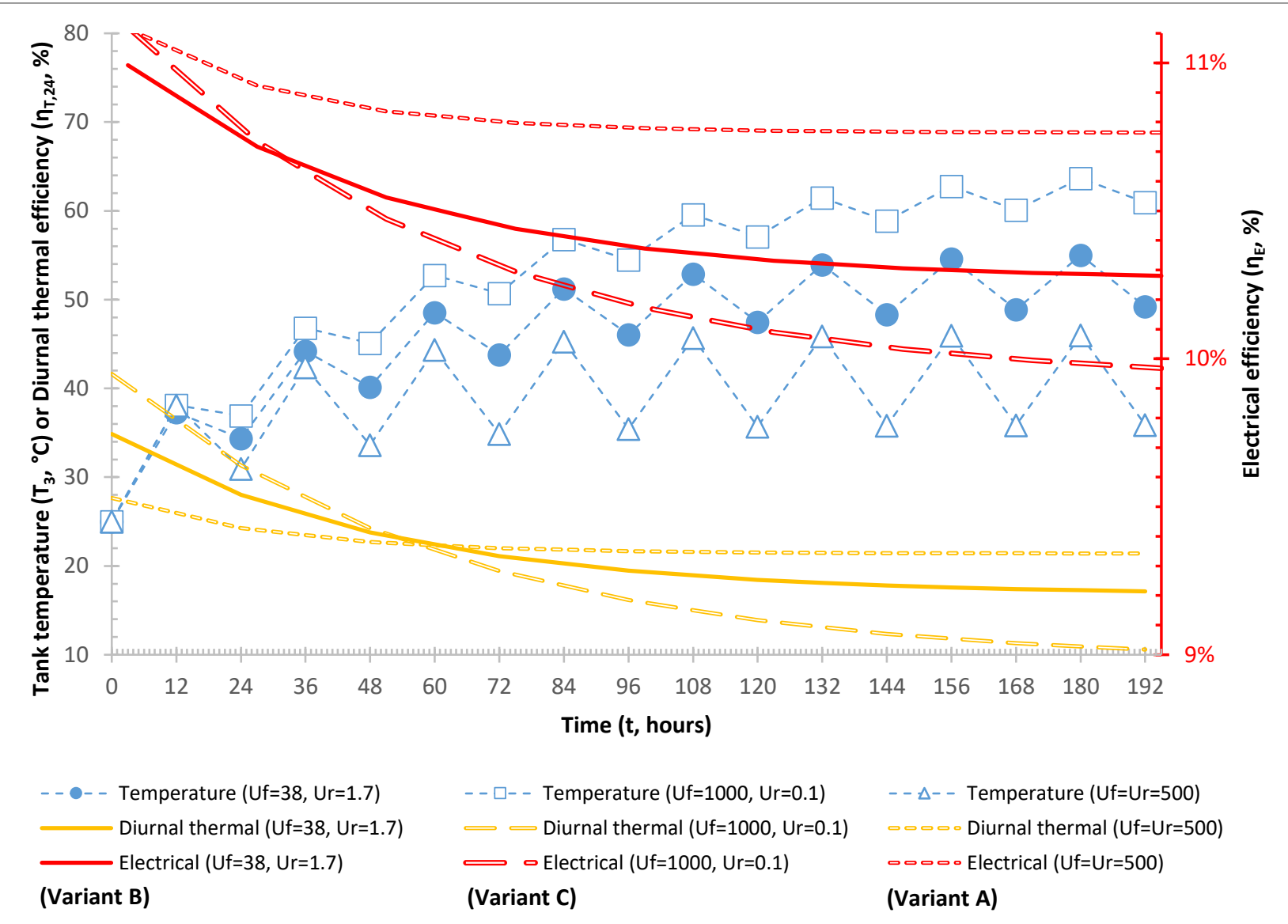

Figure 11: Comparison of tank temperature, diurnal thermal efficiency, and electrical efficiency over a multi-day period

\section{$4 \quad$ Conclusions}

850 This two-part study examines an alternative space-and-energy-efficient approach to 851 BIPV/T which combines BIPV, ICSSWH, and PLVTD concepts. This paper (Part 1 of 2) 852 has reviewed the state-of-the-art for each of the technologies and established the 853 following benchmark performance targets:

854 - Solar thermal efficiency $\eta_{T, c o l} \approx 60 \%$ at $\mathrm{N} \approx 0.035 \mathrm{~m}^{2} \mathrm{~K} \cdot \mathrm{W}^{-1}$ and $2 \mathrm{~m} / \mathrm{s}$ wind speed.

- Heat loss coefficients of $\mathrm{U}_{\mathrm{r}, \mathrm{sys}} \mathrm{A}_{\text {sys }} / \mathrm{A}_{1} \approx 1 \mathrm{~W} \cdot \mathrm{m}^{-2} \mathrm{~K}^{-1}$ and $\mathrm{U}_{\mathrm{r}, \text { sys }} \mathrm{A}_{\mathrm{sys}} / \mathrm{u} \approx 10 \mathrm{~W} \cdot \mathrm{m}^{-3} \cdot \mathrm{K}^{-1}$ at $\Delta \mathrm{T}_{3 \mathrm{a}} \approx 25^{\circ} \mathrm{C}$ and $2 \mathrm{~m} / \mathrm{s}$ wind speed.

859 A heat transfer model of a BIPV-PLVTD-ICSSWH façade element was developed to 860 enable solar thermal collection, photovoltaic generation, and overnight heat retention 861 behaviours to be evaluated under various operating scenarios. Subsequent work 862 (presented in Part 2 of 2 of this study) provides experimental validation of the model. 863 The model was interrogated based on notional $A_{1}=1 \mathrm{~m}^{2}$ solar absorber area, $75 \% \mathrm{PV}$ 
864 cell coverage, and $\mathrm{u}=100 \mathrm{~L}$ storage tank to examine how electrical and thermal 865 performances are influenced by PLVTD diodicity characteristics. Key findings can be 866 summarized as follows:

- Increasing forward mode PLVTD thermal conductance improves solar thermal and photovoltaic performances. The degree of improvement gained is dependent upon operating conditions such as irradiance, ambient temperature, heat delivery temperature, wind speed and electrical load.

- Benchmark PV and solar thermal collection targets are achievable if the PLVTD achieves $U_{f, 12}>500 \mathrm{~W} \cdot \mathrm{m}^{-2} \mathrm{~K}^{-1}$ and $\mathrm{PV}$ cell coverage is $>90 \%$, although there is only minimal benefit $(<2 \%)$ to be gained by increasing forward mode diode thermal conductance above the knee value of $U_{f, 12} \approx 100 \mathrm{~W} \cdot \mathrm{m}^{-2} \mathrm{~K}^{-1}$. Lower PLVTD conductances impair absorber-to-tank heat transfer causing high absorber temperatures which increase heat and electrical losses.

- Reducing reverse mode PLVTD thermal conductance improves overnight heat retention performance. Achieving the target benchmark would require $\mathrm{U}_{\mathrm{r}, 12}<0.5 \mathrm{~W} \cdot \mathrm{m}^{-2} \mathrm{~K}^{-1}$. Excessive heat losses and vulnerability to wind worsen significantly above a notional threshold of $\mathrm{U}_{\mathrm{r}, 12} \approx 2 \mathrm{~W} \cdot \mathrm{m}^{-2} \mathrm{~K}^{-1}$, especially when the absorber is exposed (no cover).

The model was used to predict the multi-day period behaviour of various BIPV-PLVTDICSSWH design and operating scenario variants, without thermal load. Key findings can be summarized as follows:

- During summertime in Rome (insolation $\mathrm{H}_{24}=12 \mathrm{MJ} / \mathrm{m}^{2}$, wind speed $2 \mathrm{~m} / \mathrm{s}$, ambient temperatures $\mathrm{T}_{\mathrm{a}}=25^{\circ} \mathrm{C}$ daytime and $\mathrm{T}_{\mathrm{a}}=19^{\circ} \mathrm{C}$ at night) diurnal thermal efficiency of $\eta_{T, 24}=35 \%$ and average photovoltaic efficiency of $\eta_{E} \approx 11 \%$ are predicted for the base case PLVTD $\left(U_{f, 12}=38 \mathrm{~W} \cdot \mathrm{m}^{-2} \mathrm{~K}^{-1}\right.$ and $\left.U_{r, 12}=1.7 \mathrm{~W} \cdot \mathrm{m}^{-2} \mathrm{~K}^{-1}\right)$. Solar thermal and photovoltaic performances are minimally sensitive to changes in forward mode PLVTD conductance in the range $38<U_{f, 12}<1000 \mathrm{~W} \cdot \mathrm{m}^{-2} \mathrm{~K}^{-1}$.

- Under particularly hot and sunny conditions (insolation $\mathrm{H}_{24}=20 \mathrm{MJ} / \mathrm{m}^{2}$, no wind, ambient temperatures $\mathrm{T}_{a}=35^{\circ} \mathrm{C}$ daytime and $\mathrm{T}_{a}=25^{\circ} \mathrm{C}$ at night) the model predicts that the base case BIPV-PLVTD-ICSSWH would limit maximum tank and absorber stagnation temperatures to $\mathrm{T}_{3} \approx \mathrm{T}_{0} \approx 86^{\circ} \mathrm{C}$ without the need to operate fluid circulation pumps whereas a conventional $\mathrm{PV} / \mathrm{T}$ system could reach a potentially damaging $\mathrm{T}_{3} \approx \mathrm{T}_{0} \approx 106^{\circ} \mathrm{C}$ and would require pumps to be energised 
continuously during collection periods to prevent even higher $\left(T_{0}>150^{\circ} \mathrm{C}\right)$ temperatures developing.

- Overnight heat retention is very sensitive to changes in reverse mode PLVTD conductance such that increasing or decreasing in the range $0.1<\mathrm{U}_{\mathrm{r}, 12}<500 \mathrm{~W} \cdot \mathrm{m}^{-2} \mathrm{~K}^{-1}$ changes diurnal thermal efficiency by $\pm 7 \%$ relative to the base case $\left(U_{r, 12}=1.7 \mathrm{~W} \cdot \mathrm{m}^{-2} \mathrm{~K}^{-1}\right)$. Pronounced heat losses occur during winter

906 The passive BIPV-PLVTD-ICSSWH approach to controlling overheating significantly 907 reduces the risk of stagnation damage and increases net electrical yields compared to 908 conventional BIPV/T approaches. This alternative approach to BIPV/T could have 909 positive impacts in the context of realising NZEBs as part of global efforts to tackle the 910 climate crisis.

\section{Acknowledgements}

912 This research was enabled in its early stages by studentship funding support from the

913 Northern Ireland Department for the Economy. The work was subsequently progressed 914 with funding support from SolaForm Ltd and was completed as part of the 915 "SolaNetwork" project funded by the UKRI Engineering and Physical Sciences Research 916 Council (EP/T004819/1). The authors would also like to thank networking support 917 funded by the European Union FP7 COST Action TU1205 "Building Integration of Solar 918 Thermal Systems".

\section{Nomenclature}

\section{Latin symbols}

921 A Surface area $\left[\mathrm{m}^{2}\right]$

$922 \mathrm{C}_{\mathrm{p}} \quad$ Specific heat capacity at constant pressure $\left[\mathrm{J} \cdot \mathrm{kg}^{-1} \mathrm{~K}^{-1}\right]$

923 FF Photovoltaic Fill Factor [\%]

$924 \mathrm{G} \quad$ Solar irradiance $[\mathrm{W} \cdot \mathrm{m}-2$ ]

$925 \quad \mathrm{H} \quad$ Solar insolation $\left[\mathrm{MJ} \cdot \mathrm{m}^{-2}\right]$

926 । Electrical current $[\mathrm{A}]$

$927 \mathrm{k} \quad$ Thermal conductivity $\left[\mathrm{W} \cdot \mathrm{m}^{-1} \mathrm{~K}^{-1}\right]$

$928 \mathrm{~K} \quad$ Photovoltaic performance correction coefficients [\% or \% $/ \mathrm{K}]$

$929 \mathrm{~m} \quad$ Mass $[\mathrm{kg}]$

$930 \mathrm{M} \quad$ Mass flow rate $\left[\mathrm{kg} \cdot \mathrm{s}^{-1}\right]$

$931 \mathrm{~N} \quad$ Solar Thermal Condition $\left[\mathrm{m}^{2} \cdot \mathrm{K} \cdot \mathrm{W}^{-1}\right]$

$932 \mathrm{q}$ Thermal or electrical power [W]

$933 Q_{[t]} \quad$ Thermal energy, cumulative during time period [MJ] 


$\begin{array}{lll}934 & \mathrm{PR} & \text { Performance ratio }[\%] \\ 935 & \mathrm{R} & \text { Thermal or electrical resistance }\left[\mathrm{K} \cdot \mathrm{W}-{ }^{-1}\right] \\ 936 & \mathrm{t} & \text { Time }[\mathrm{s}] \\ 937 & \mathrm{~T} & \text { Temperature }\left[{ }^{\circ} \mathrm{C}\right] \\ 938 & \widetilde{T}_{[t]} & \text { Average temperature, during time period }\left[{ }^{\circ} \mathrm{C}\right] \\ 939 & \mathrm{u} & \text { Volume }\left[\mathrm{m}^{3}\right] \\ 940 & \mathrm{U} & \text { Thermal conductance or heat transfer coefficient }\left[\mathrm{W} \cdot \mathrm{m}^{-2} \mathrm{~K}-{ }^{-1}\right] \\ 941 & \mathrm{~V} & \text { Electrical voltage }[\mathrm{V}] \\ 942 & \mathrm{x} & \text { Distance along an axis which is parallel to the PLVTD depth }[\mathrm{m}] \\ 943 & \mathrm{y} & \text { Distance along horizontal axis perpendicular to PLVTD depth }[\mathrm{m}] \\ 944 & \mathrm{z} & \text { Distance along an axis which is perpendicular to } \mathrm{x} \text { and } \mathrm{y} \text { axes }[\mathrm{m}] \\ 945 & & \end{array}$

\section{Greek and other symbols}

$947 \alpha$

Absorptivity

$948 \varepsilon$

Emissivity

$949 \Delta T$

Temperature difference $\left[{ }^{\circ} \mathrm{C}\right]$

$950 \eta$

Efficiency [\%]

$951 \varsigma$

Diodicity [\%]

$952 \tau$

Transmissivity

953

\section{Subscripts}

9550

9561

9572

9583

9594

9605

9616

962 0a

96303

964 1a

$965 \quad 12$

$966 \quad 15$

$967 \quad 23$

$968 \quad 24$

969 3a

$970 \quad 3$ ia

971365

$972 \quad 4 a$

$973 \quad 56$

$9746 a$

$975 \quad a$

976 avg

$977 \mathrm{col}$

$978 \quad E$

$979 \mathrm{f}$

$980 \mathrm{~h}$
Photovoltaic cells

Planar Liquid-Vapour Thermal Diode, Plate 1 which is the evaporator in forward mode

Planar Liquid-Vapour Thermal Diode, Plate 2 which is the condenser on forward mode

Hot water storage tank

Sidewalls of the Planar Liquid-Vapour Thermal Diode

External surface of the solar absorber

Transparent element covering solar absorber

Between PV cells and ambient environment

Between PV cells and hot water storage tank

Between solar absorber and ambient environment

Between (or average of the two plates

Between the PLVTD and the external surface of the solar absorber (through the laminate)

Between the PLVTD and the water storage tank

Diurnal period of 24 hours

Between water storage tank and ambient environment

Between water storage tank and ambient environment through insulation

Annual period of 365 days

Between PLVTD sidewalls and ambient environment

Across the air gap between the solar absorber and transparent cover

Between the transparent cover and the ambient environment

Ambient environment

Average

Collection (period of solar absorber illumination, eg daytime)

Electrical

Forward mode

Horizontal orientation 


$\begin{array}{lll}981 & \text { inst } & \text { Instantaneous } \\ 982 & \text { L } & \text { Loss to ambient environment } \\ 983 & \text { load } & \text { Applied electrical load } \\ 984 & \text { mpp } & \text { Maximum Power Point } \\ 985 & \text { oc } & \text { Open circuit } \\ 986 & \text { P } & \text { Pump } \\ 987 & \text { PV } & \text { Photovoltaic } \\ 988 & \text { r } & \text { Reverse mode } \\ 989 & \text { ret } & \text { Retention (period without solar absorber illumination, eg night-time) } \\ 990 & \text { sC } & \text { Short circuit } \\ 991 & \text { STC } & \text { At Standard Test Conditions } \\ 992 & \text { sys } & \text { Whole system } \\ 993 & \text { T } & \text { Thermal } \\ 994 & \text { T3 } & \text { At the hot water storage tank temperature } \\ 995 & \text { I:T } & \text { Current-Temperature relationship } \\ 996 & \text { V:T } & \text { Voltage-Temperature relationship } \\ 997 & \text { V:G } & \text { Voltage-Irradiance relationship } \\ 998 & & \end{array}$

\section{Abbreviations}

1000 a-si Amorphous silicon

1001 BIPV Building Integrated PhotoVoltaics

1002 BISTS Building Integrated Solar Thermal Systems

1003 CdTe Cadmium Telluride

1004 CIGS Copper Indium Gallium Selenium

1005 ICSSWH Integrated Collector-Storage Solar Water Heater

1006 mc-si Mono-crystalline silicon

1007 NZEB Net Zero Energy Building

1008 pc-si Poly-crystalline silicon

1009 PLVTD Planar Liquid-Vapour Thermal Diode

$1010 \quad \mathrm{PV} / \mathrm{P} \quad$ Photovoltaic-Thermal

\section{References}

1012 Abdelrazik, A., Al-Sulaiman, F., Saidur, R., Ben-Mansour, R. (2018). A review on recent development for the design and packaging 1013 of hybrid photovoltaic/thermal (PV/T) solar systems. Renewable and Sustainable Energy Reviews 95 (2018) 110-129

1014 Amerongen, G., Lee, J., Suter, J. (2013). Legionella and solar water heaters. Report commissioned by the Solar Certification Fund. 1015 Available at: <www.estif.org/solarkeymarknew/images/downloads/SCF/scfdeliverables/Report\%20SCF\%20Legionella\%20and\%20 1016 solar\%20water\%20heaters\%20\%20Final\%202013\%2004.pdf>

1017 Barone, G., Buonomano, A., Forzano, C., Palombo, A., Panagopoulos, O. (2019). Photovoltaic thermal collectors: Experimental 1018 analysis and simulation model of an innovative low-cost water-based prototype. Energy 179 (2019) 502-516

1019 Beausoleil-Morrison, I., Kemery, B., Wills, A., Meister, C. (2019). Design and simulated performance of a solar-thermal system 1020 employing seasonal storage for providing the majority of space heating and domestic hot water heating needs to a single-family 1021 house in a cold climate. Solar Energy 191 (2019) 57-69

1022 Belussi, L., Barozzi, B., Bellazzi, A., Danza, L., Devitofrancesco, A., Fanciulli, C., Ghellere, M., Guazzi, G., Meroni, I., Salamone, F., 1023 Scamoni, F., Scrosati, C. (2019). A review of performance of zero energy buildings and energy efficiency solutions. Journal of Building 1024 Engineering 25 (2019) 100772

1025 Besheer, A., Smyth, M., Zacharopoulos, A., Mondol, J., Pugsley, A. (2016). Review on recent approaches for hybrid PV/T solar 1026 technology. International Journal of Energy Research. DOI: 10.1002/er.3567

1027 Bilardo, M., Fraisse, G., Pailha, M., Fabrizio, E. (2019). Modelling and performance analysis of a new concept of integral collector 1028 storage (ICS) with phase change material. Solar Energy 183 (2019) 425-440 
Borello, D., Corsini, A., Delibra, G., Evangelisti, S., Micangeli, A. (2012). Experimental and computational investigation of a new solar integrated collector storage system. Applied Energy 97 (2012) 982-989

Boreyko, J. \& Chen, C. (2013). Vapor chambers with jumping-drop liquid return from superhydrophobic condensers. International Journal of Heat and Mass Transfer 61 (2013) 409-418

Bosch (2010). High performance - Stable yields. Bosch Solar Cell M 2BB. [Last accessed: 10 September 2016]. Arnstadt, Germany: Bosch Solar Energy AG. Available at: <http://www.bosch-solarenergy.com>.

1035

1036

1037

1038

1039

1040

1041

1042

1043

1044

1045

1046

1047

1048

1049

1050

1051

1052

1053

1054

1055

1056

1057

1058

1059

1060

1061

1062

1063

1064

1065

1066

1067

1068

1069

1070

1071

1072

1073

1074

1075

1076

1077

1078

1079

1080

Buonomano, A., Calise, F., Palombo, A., Vicidomini, M. (2016). BIPVT systems for residential applications: An energy and economic analysis for European climates. Applied Energy 184 (2016) 1411-1431

Calise, F., d'Accadia, M, Figaj, R., Vanoli, L., (2016). A novel solar-assisted heat pump driven by photovoltaic/thermal collectors: Dynamic simulation and thermoeconomic optimization. Energy 95, 346-66

Chaabane, M., Mhiri, H., Bournot, P. (2014). Thermal performance of an integrated collector storage solar water heater (ICSSWH) with phase change materials (PCM). Energy Conversion and Management 78 (2014) 897-903.

COST Action TU1205 (2015). Overview of BISTS state of the art, models and applications. ISBN: 978-9963-697-16-8. Cyprus University of Technology / European Union Horizon 2020.

Das, D., Kalita, P., Roy, O. (2018). Flat plate hybrid photovoltaic- thermal (PV/T) system: A review on design and development. Renewable and Sustainable Energy Reviews 84 (2018) 111-130

De Beijer, H. (1998). Product development in solar water heating. Renewable Energy 5 (1998) 201-204

Deng, J., O'Donovan, T., Tian, Z., King, J., Speake, S. (2019). Thermal performance predictions and tests of a novel type of flat plate solar thermal collectors by integrating with a freeze tolerance solution. Energy Conversion and Management 198 (2019) 111784

DGS - Deutsche Gesellshaft fur Sonnenenergie (2008). Planning and Installing Photovoltaic Systems - A guide for installers, architects and engineers. 2nd ed. London: Earthscan. ISBN-13: 978-1-84407-442-6

Drosou, V., Tsekouras, P., Oikonomou, T., Kosmopoulos, P., Karytsas, C. (2014). The HIGH-COMBI project: High solar fraction heating and cooling systems with combination of innovative components and methods. Renewable and Sustainable Energy Reviews 29 (2014) $463-472$

Dupeyrat, P., Menezo, C., Rommel, M., Henning, H. (2011). Efficient single glazed flat plate photovoltaic-thermal hybrid collector for domestic hot water systems. Solar Energy 85, 1457-68

Eames, P. and Griffiths, P. (2006). Thermal behaviour of integrated solar collector/storage unit with 65C phase change material. Energy Conversion and Management 47 (2006) 3611-3618

Faiman, D., Hazan, H. and Laufer, I. (2001). Reducing the Heat Loss at Night from Solar Water Heaters of the Integrated CollectorStorage Variety. Solar Energy, 71 (2) 87-93

Fuentes, M., Vivar, M., Casab, J., Aguilera, J. (2018). An experimental comparison between commercial hybrid PV-T and simple PV systems intended for BIPV. Renewable and Sustainable Energy Reviews 93 (2018) 110-120

Garnier, C., Currie, J., Muneer,T. (2009). Integrated collector storage solar water heater: Temperature stratification. Applied Energy 86 (2009) 1465-1469

Good, C., Andresen, I., Hestnes, A. (2015). Solar energy for net zero energy buildings - A comparison between solar thermal, PV and photovoltaic-thermal (PV/T) systems. Solar Energy 122, 986-96

Guarracino, I., Freeman, J., Ramos, A., Kalogirou, S., Ekins-Daukes, N., Markides, C. (2019). Systematic testing of hybrid PV-thermal (PVT) solar collectors in steady-state and dynamic outdoor conditions. Applied Energy 240 (2019) 1014-1030

Harmim, A., Boukar, M., Amar, M., Haida, A. (2019). Simulation and experimentation of an integrated collector storage solar water heater designed for integration into building façade. Energy 166 (2019) 59-71

IEA - International Energy Agency (2018). Key World Energy Statistics 2018. Paris, France: IEA.

IEA/UN - International Energy Agency and the United Nations Environment Programme (2018). 2018 Global Status Report: towards a zero-emission, efficient and resilient buildings and construction sector. Paris, France: IEA for the Global Alliance for Buildings and Construction (GlobalABC). ISBN: 978-92-807-3729-5.

Kalogirou, S. (2009). Solar energy engineering. London: Academic Press (Elsevier) ISBN 13: 978-0-12-374501-9

Kats, G., Seal, A. (2012). Buildings as Batteries: The Rise of 'Virtual Storage'. The Electricity Journal 25 (10) $59-70$ http://dx.doi.org/10.1016/j.tej.2012.11.004

Krauter, S. (2004). Development of an integrated solar home system. Solar Energy Materials \& Solar Cells 82 (2004) 119-130

Li, S., Zhang, Y., Zhang, K., Li, X., Li, Y., Zhang, X. (2013). Study on performance of storage tanks in solar water heater system in charge and discharge progress (SHC 2013, International Conference on Solar Heating and Cooling for Buildings and Industry). Energy Procedia 48 (2014) 384-393 doi: 10.1016/j.egypro.2014.02.045

Li, X., Lin, A., Young, C., Dai, Y., Wang, C. (2019). Energetic and economic evaluation of hybrid solar energy systems in a residential net-zero energy building. Applied Energy 254 (2019) 113709 
Mehdaoui, F., Hazami, M., Messaouda, A., Guizani, A. (2019). Performance analysis of two types of Solar Heating Systems used in

buildings under typical North-African climate (Tunisia). Applied Thermal Engineering

(AIP)

1084

1085 https://doi.org/10.1016/j.applthermaleng.2019.114203

Michael, J., Iniyan, S., Goic, R. (2015). Flat plate solar photovoltaic-thermal (PV/T) systems. Renewable \& Sustainable Energy Reviews $51,62-88$

Mohamad, A. (1997). Integrated Solar Collector-Storage Tank System with Thermal Diode. Solar Energy 61 (3) 211-218

Muhumuza, R., Zacharopoulos, A., Mondol, J., Smyth, M. (2019a). Experimental study of heat retention performance of thermal diode Integrated Collector Storage Solar Water Heater (ICSSWH) configurations. Sustainable Energy Technologies and Assessments 34 (2019) 214-219

1090

1091

Muhumuza, R., Zacharopoulos, A., Mondol, J., Smyth, M., Pugsley, A., Giuzio, G., Kurmis, D. (2019b). Experimental investigation of horizontally operating thermal diode solar water heaters with differing absorber materials under simulated conditions. Renewable Energy, Volume 138, August 2019, Pages 1051-1064

1093

1094

1095

Muhumuza, R., Zacharopoulos, A., Mondol, J., Smyth, M., Pugsley, A., McGee, J. (2020). Simulation and experimental validation of solar radiation distribution on the absorber of a line-axis asymmetric compound parabolic concentrator. Solar Energy 198 (2020) $36-$ 52. https://doi.org/10.1016/j.solener.2020.01.033.

1096

1097

1098

NASA - National Aeronautics and Space Administration (2019). Data Access Viewer for Prediction of Worldwide Energy Resource (POWER) Project funded through the NASA Earth Science/Applied Science Program. Hampton, USA: Langley Research Center (LaRC). Available at: < https://power.larc.nasa.gov/data-access-viewer/ > [Last accessed: 07/10/19].

1099

O'Hegarty, R., Kinnane, O., McCormack, S. (2014). A Case for façade located solar thermal collectors. (International Conference on

1100

1101

1102

1103

1104

1105

1106

1107

1108

Solar Heating and Cooling for Buildings and Industry, SHC 2014). Energy Procedia 70 (2015) 103-110 doi: 10.1016/j.egypro.2015.02.104

Pugsley, A., Mondol, J., Smyth, M., Zacharopoulos, A., Di Mattia, L. (2016). Experimental characterisation of a flat panel integrated collector-storage solar water heater featuring a photovoltaic absorber and a planar liquid-vapour thermal diode. Proceedings of 11th ISES EuroSun Conference: Palma (Mallorca), Spain from 11 to 14 October 2016. Martinez, V. \& Gonzalez, J. (eds.).

Pugsley, A. (2017). Theoretical and experimental analysis of a novel flat photovoltaic-thermal solar water heater with integrated energy storage via a planar liquid-vapour thermal diode. Ulster University PhD Thesis (uk.bl.ethos.713462) published July 2017.

Pugsley, A., Zacharopoulos, A., Mondol, J., Smyth, M. (2019). Theoretical and experimental analysis of a horizontal Planar LiquidVapour Thermal Diode (PLVTD). International Journal of Heat and Mass Transfer 144 (2019) 11866

Pugsley, A., Zacharopoulos, A., Mondol, J., Smyth, M. (2020). Vertical Planar Liquid-Vapour Thermal Diodes (PLVTD) and their application in building façade energy systems. Applied Thermal Engineering (submitted for publication 01/2020, under review)

Qu, M., Chen, J., Nie, L., Li, F., Yu, Q., Wang, T. (2016). Experimental study on the operating characteristics of a novel photovoltaic/thermal integrated dual-source heat pump water heating system. Applied Thermal Engineering 94, 819-26

1113 Quinlan, P. (2010). The Development of a Novel Integrated Collector Storage Solar Water Heater (ICSSWH) Using Phase Change

Rhee, J., Campbell, A. Mariadass, A., Morhous, B. (2010). Temperature stratification from thermal diodes in solar hot water storage tank. Solar Energy 84 (2010) 507-511

Santbergen, R., Rindt, C., Zondag, H., Van Zolingen, R. (2010). Detailed analysis of the energy yield of systems with covered sheetand-tube PVT collectors. Solar Energy 84, 867-78.

1119 Saretta, E., Bonomo, P., Frontini, F. (2020). A calculation method for the BIPV potential of Swiss façades at LOD2.5 in urban areas: 1120 A case from Ticino region. Solar Energy 195 (2020) 150-165

1121 Schmidt, C. and Goetzberger, A. (1990). Single-Tube Integrated Collector Storage Systems with Transparent Insulation and Involute 1122 Reflector. Solar Energy 45 (2) 93-100

Singh, R., Lazarus, I., Souliotis, M. (2016). Recent developments in integrated collector storage (ICS) solar water heaters: A review. Renewable \& Sustainable Energy Reviews 54, 270-98

Smyth, M., Eames, P., Norton, B. (1999). A comparative performance rating for an integrated solar collector/storage vessel with inner sleeves to increase heat retention. Solar Energy 66 (4) 291-303.

1127 Smyth, M., Eames, P., Norton, B. (2003). Heat Retaining Integrated Collector/Storage Solar Water Heaters. Solar Energy 75 (2003) 27-34

1129 Smyth, M., McGarrigle, P., Eames, P., Norton, B. (2005). Experimental comparison of alternative convection suppression arrangements for concentrating integral collector storage solar water heaters. Solar Energy 78 (2005) 223-233 
Smyth, M., Besheer, A., Zacharopoulos, A., Mondol, J., Pugsley, A., Novaes, M. (2015b). Experimental evaluation of a Hybrid Photovoltaic/Solar Thermal (HyPV/T) Façade Module. Proceedings EURO ELECS Conference 21-23 July 2015, Guimarães, Portugal.

Smyth, M., Quinlan, P., Mondol, J., Zacharopoulos, A., McLarnon, D., Pugsley, A. (2017). The evolutionary thermal performance \& development of a novel thermal diode pre-heat solar water heater under simulated heat flux conditions. Renewable Energy 113 (2017) 1160-1167

Smyth, M., Quinlan, P., Mondol, J., Zacharopoulos, A., McLarnon, D., Pugsley, A. (2018). The experimental evaluation and improvements of a novel thermal diode pre-heat solar water heater under simulated solar conditions. Renewable Energy 121 (2018) 116-122

Smyth, M., Pugsley, A., Hanna, G., Zacharopoulos, A., Besheer, A., Savvides, A. (2019). Experimental performance characterisation of a Hybrid Photovoltaic/Solar Thermal Façade module compared to a flat Integrated Collector Storage Solar Water Heater module.

1143 Renewable Energy 137 (2019) 137-143

1144 Sopian, K., Syahri, M., Abdullah, S., Othman, M.,Yatim, B. (2004). Performance of a non-metallic unglazed solar water heater with integrated storage system. Renewable Energy 29 (2004) 1421-1430

1146 Souliotis, M., Quinlan, P., Smyth, M., Tripanagnostopoulos, Y., Zacharopoulos, A., Ramirez, M., Yianoulis, P. (2011). Heat retaining integrated collector storage solar water heater with asymmetric CPC reflector. Solar Energy 85 (2011) 2474-87

Souliotis, M., Chemisana, D., Caouris, Y., Tripanagnostopoulos, Y. (2013). Experimental study of integrated collector storage solar water heaters. Renewable Energy 50 (2013) 1083-1094

Souliotis, M., Papaefthimiou, S., Caouris, Y., Zacharopoulos, A., Quinlan, P., Smyth, M. (2017). Integrated collector storage solar water heater under partial vacuum. Energy 139 (2017) 991-1002

1152 Stackhouse, P., Zhang, T., Westberg, D., Barnett, A., Bristow, T., Macpherson, B., Hoell, J. (2018). POWER Release 8.0.1 (with GIS 1153 Applications) Methodology, Data Parameters, Sources, \& Validation. Data Version 8.0.1. Web Site Version 1.1.0. Hampton, USA: 1154 NASA LaRC, Langley Research Center.

1155 Sultan, S., Efzan, E. (2018). Review on recent Photovoltaic/Thermal (PV/T) technology advances and applications. Solar Energy $1156173(2018) 939-954$

1157 Tian, M., Yu, X., Su, Y., Zheng, H., Riffat, S. (2019). A study on incorporation of transpired solar collector in a novel multifunctional 1158 PV/Thermal/Daylighting (PV/T/D) panel. Solar Energy 165 (2018) 90-99

1159 Tripanagnostopoulos, Y., Souliotis, M., Nousia, T. (2002). CPC type collector storage systems. Solar Energy 72 (4) 327-350

1160 Tripanagnostopoulos, Y., Souliotis, M. (2006). ICS Solar Systems with Two Water Tanks. Renewable Energy 29 (1) 13-38

1161 Twidell, J. \& Weir, T. (2006). Renewable Energy Resources (2nd ed.) London: Taylor Francis. ISBN13:9-78-0-419-25330-3

1162 Yang, T., Athienitis, A. (2016). A review of research and developments of building-integrated photovoltaic/thermal (BIPV/T) systems. 1163 Renewable and Sustainable Energy Reviews 66 (2016) 886-912

1164 Ziapour, B., Palideh, V., Mohammadnia, A. (2014). Study of an improved integrated collector-storage solar water heater combined 1165 with the photovoltaic cells. Energy Conversion and Management 86 (2014) 587-594.

1166 Zondag, H. (2008). Flat-plate PV-thermal collectors and systems: a review. Renewable \& Sustainable Energy Reviews 12, 891-959. 